\title{
International Journal, SSR, management@ssr.com, 27.02.2012 Population and economic growth theme: Longitudinal data for a sample of Balkan countries
}

\author{
Dushko Josheski (dushkojosheski@gmail.com) \\ Nikola V.Dimitrov (nikola.dimitrov@ugd.edu.mk) \\ Cane Koteski (cane.koteski@ugd.edu.mk) \\ University Goce Delcev-Stip
}

\begin{abstract}
In this paper we use pooled cross-sectional (longitudinal data) in a sample of 10 Balkan countries. The period we cover is from 1950-2009 data are for population and economic growth. In the theoretical part we present optimal intergenerational model of population growth .The optimal population growth depends on capital in the future period and future consumption. Consumption should be greater than zero, and less than total capital of the current generation. In the econometric part OLS regression with dummies the coefficient on Macedonia, is highest significant coefficient meaning, if we control for Macedonia we will on average find more positive association between growth of GDP and population growth. Hausman test was in favor of fixed effects model, but fixed effects and Random effects model showed that there is positive coefficient between GDP growth and population growth. Coefficient in the FE model was statistically significant, which was not case in RE model. From the Fischer's panel unit root test we reject the null hypothesis that panels contain unit root and we accept the alternative that at least one panel is stationary, for the population growth and GDP growth.
\end{abstract}

Keywords: Population growth, economic growth, Fixed effects model, Random effects model, OLS with dummies model 


\section{Introduction}

In the beginning of the theoretical section we will start with (Kremer, (1993) $)^{1}$ evidence that the relationship between population growth and population is almost linear but also statistically significant. In this section we will use our data on population and population growth (See Section data and methodology for explanations $)^{2}$.This data cover 10 Balkan countries ,panel data that cover time period for every of the 10 Balkan countries from 1950 to 2009 The level and growth population are presented in the next scatter

\section{Scatter level of population and population growth}

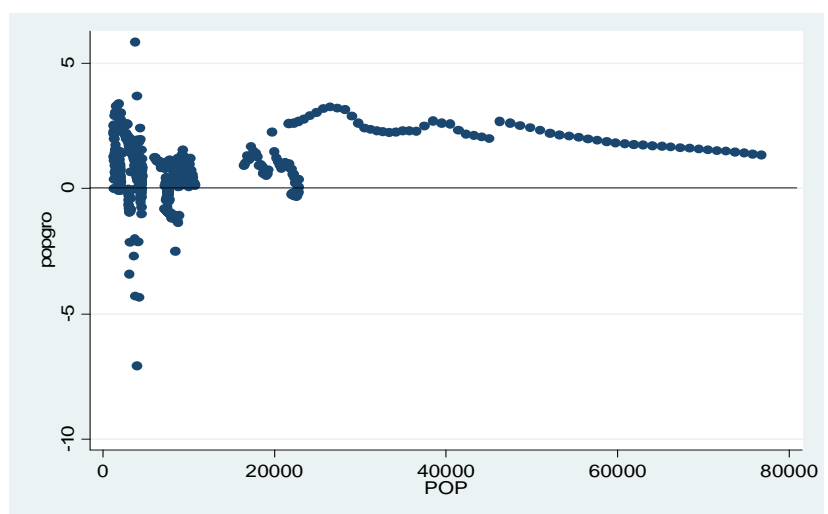

This figure shows strongly positive and as we will see statistically significant relationship between population (in thousands) and growth of population.

A regression on a constant and population (in thousands) yields (See Appendix 1) ${ }^{3}$ :

$$
\begin{aligned}
& \text { popgro }=0.58+0.0000196 \text { pop } \\
& (0.000) \quad(0.000) \\
& \mathrm{R}^{2}=0.06
\end{aligned}
$$

Here popgro is population growth and pop is population in thousands, score is positive and statistically significant at all levels of conventional significance. On the next 2 tables we present the data on GDP and Population growth for the 10 Balkan countries from 2001-2010.

\footnotetext{
${ }^{1}$ Michael Kremer (1993), "Population Growth and Technological Change: One Million B.C. to 1990," Quarterly Journal of Economics 108:3 (August), pp. 681-716.

${ }^{2}$ See Section data and methodology for explanations.

${ }^{3}$ See Appendix 1 Regression on population growth and level of population
} 
Table 1 Population growth in 10 Balkan countries for the period $2001-2010^{4}$

$\begin{array}{lrrrrrrrrrr}\text { Country Name } & 2001 & 2002 & 2003 & 2004 & 2005 & 2006 & 2007 & 2008 & 2009 & 2010 \\ \text { Albania } & 0.18 & 0.40 & 0.55 & 0.58 & 0.54 & 0.47 & 0.41 & 0.37 & 0.36 & 0.36 \\ \text { Bosnia and } & 1.47 & 0.73 & 0.18 & -0.04 & -0.01 & 0.02 & -0.07 & -0.13 & -0.17 & -0.20 \\ \text { Herzegovina } & -1.88 & -0.52 & -0.59 & -0.54 & -0.53 & -0.53 & -0.51 & -0.48 & -0.50 & -0.55 \\ \text { Bulgaria } & 0.32 & 0.00 & 0.00 & -0.02 & 0.07 & -0.05 & -0.09 & -0.05 & -0.11 & -0.11 \\ \text { Croatia } & 0.30 & 0.34 & 0.33 & 0.35 & 0.38 & 0.40 & 0.40 & 0.40 & 0.41 & 0.32 \\ \text { Greece } & 0.35 & 0.31 & 0.27 & 0.26 & 0.25 & 0.24 & 0.24 & 0.22 & 0.21 & 0.18 \\ \text { Macedonia, } & -1.40 & -1.50 & -0.28 & -0.26 & -0.23 & -0.22 & -0.19 & -0.15 & -0.15 & -0.18 \\ \text { FYR } & -0.17 & -0.05 & -0.26 & -0.23 & -0.30 & -0.39 & -0.41 & -0.43 & -0.40 & -0.39 \\ \text { Romania } & 0.15 & 0.10 & 0.09 & 0.07 & 0.18 & 0.32 & 0.56 & 0.16 & 0.90 & 0.64 \\ \text { Serbia } & 1.43 & 1.39 & 1.36 & 1.34 & 1.34 & 1.34 & 1.34 & 1.32 & 1.29 & 1.25 \\ \text { Slovenia } & & & & & & & & & \\ \text { Turkey } & \text { Ban } & & & & & \end{array}$

Source: World Bank

Table 2 GDP growth in 10 Balkan countries for the period 2001-2010

$\begin{array}{lrrrrrrrrrr}\text { Country Name } & 2001 & 2002 & 2003 & 2004 & 2005 & 2006 & 2007 & 2008 & 2009 & 2010 \\ \text { Albania } & 7.00 & 2.90 & 5.70 & 5.90 & 5.50 & 5.00 & 5.90 & 7.70 & 3.30 & 3.50 \\ \text { Bosnia and } & 4.40 & 5.30 & 4.00 & 6.10 & 5.00 & 6.20 & 6.84 & 5.42 & -3.10 & 0.80 \\ \text { Herzegovina } & & & & & & & & \\ \text { Bulgaria } & 4.15 & 4.65 & 5.51 & 6.75 & 6.36 & 6.51 & 6.45 & 6.22 & -5.52 & 0.20 \\ \text { Croatia } & 3.66 & 4.88 & 5.37 & 4.13 & 4.28 & 4.94 & 5.06 & 2.17 & -5.99 & -1.19 \\ \text { Greece } & 4.20 & 3.44 & 5.94 & 4.37 & 2.28 & 5.17 & 4.28 & 1.02 & -2.04 & -4.47 \\ \text { Macedonia, } & -4.53 & 0.85 & 2.82 & 4.09 & 4.10 & 3.95 & 5.90 & 5.00 & -0.90 & 0.70 \\ \text { FYR } & 5.70 & 5.10 & 5.20 & 8.40 & 4.17 & 7.90 & 6.00 & 9.43 & -8.50 & 0.95 \\ \text { Romania } & 5.60 & 3.90 & 2.40 & 8.30 & 5.60 & 5.23 & 6.90 & 5.52 & -3.12 & 1.76 \\ \text { Serbia } & 2.85 & 3.97 & 2.84 & 4.29 & 4.49 & 5.81 & 6.80 & 3.49 & -7.80 & 1.18 \\ \text { Slovenia } & -5.70 & 6.16 & 5.27 & 9.36 & 8.40 & 6.89 & 4.67 & 0.66 & -4.83 & 8.95 \\ \text { Turkey } & & & & & & & & & & \end{array}$

Source: World Bank

On the next scatter are presented average growth rates of population and GDP, we add a linear trend to the scatter and GDP growth is negatively correlated with the population growth by -0.24 and intercept is 3.65 . This means that if population increases by 1 percentage point GDP growth on average will decline by 0.24 percentage points.

\section{Scatter GDP growth on population growth}

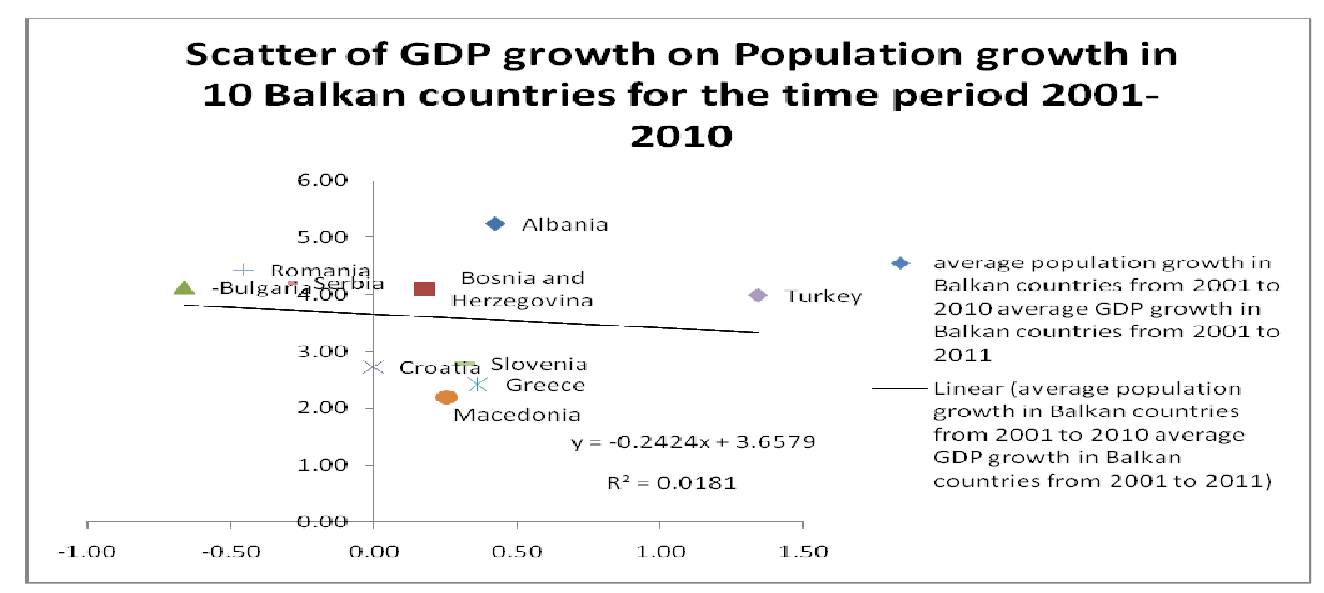

\footnotetext{
${ }^{4}$ These data are gathered from World Bank data base: http://data.worldbank.org/country.
} 
Population growth rate is very slow in the Balkans.Especially in Bulgaria (-0.66), Romania (-0.46), Serbia(-0.30), have negative population growth rate (see chart below).Croatia (0.0) doesn't have population growth, Bosnia and Herzegovina (0.18), Macedonia (0.25), Greece(0.36), Slovenia (0.32), Albania (0.42) and Turkey(1.34).

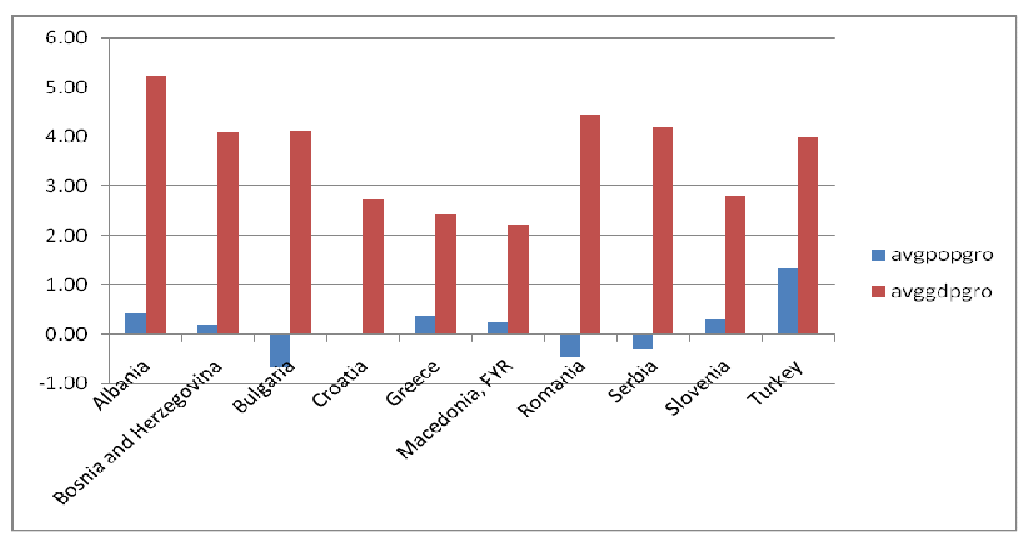

The demographic structure will be very old in the next decades. This can bring social security problems similar to those of Germany and the other Western European countries.Albania has highest average GDP growth (5.24), followed by Romania(4.43), Serbia(4.21), Bulgaria(4.13), Bosnia and Herzegovina (4.10), Slovenia(2.79), Croatia(2.73), Greece (2.42), Macedonia (2.20). Macedonia has lowest GDP growth from 2001-2010.

\section{Population growth theories}

Malthus prediction, made in 1801 that population growth would run up against the fixity of earth's resources and condemn most of the population to poverty and high death rates proved wrong. Kuznets defined growth in 1966 as sustained increase in population attained without any lowering of per capita product, and viewed population growth as positive contributor to economic growth (Birdsall,N.,(1988) $)^{5}$.

Table 3 Natural increase in population in the World by economies and regions

\begin{tabular}{|l|c|c|c|c|c|c|c|c|c|}
\hline \multicolumn{8}{|c|}{ Birth and death rates of natural increase, by region, 1950-1955 to 1980-85 } \\
\hline & \multicolumn{3}{|c|}{ Crude birth rate } & \multicolumn{3}{c|}{ Crude death rate } & \multicolumn{3}{c|}{ Natural increase } \\
\cline { 2 - 12 } & $1950-55$ & $1960-65$ & $1980-85$ & $1950-55$ & $1960-65$ & $1980-85$ & $1950-55$ & $1960-65$ & $1980-85$ \\
\hline $\begin{array}{l}\text { Developed } \\
\text { countries }\end{array}$ & 22.7 & 20.3 & 15.5 & 10.1 & 9.0 & 9.6 & 1.3 & 1.1 & 0.6 \\
\hline $\begin{array}{l}\text { Developing } \\
\text { countries }\end{array}$ & 44.4 & 41.9 & 31.0 & 24.2 & 18.3 & 10.8 & 2.0 & 2.4 & 2.0 \\
\hline Africa & 48.3 & 48.2 & 45.9 & 27.1 & 23.2 & 16.6 & 2.1 & 2.5 & 2.9 \\
\hline $\begin{array}{l}\text { Latin } \\
\text { America }\end{array}$ & 42.5 & 41.0 & 31.6 & 15.4 & 12.2 & 8.2 & 2.7 & 2.9 & 2.3 \\
\hline East Asia & 43.4 & 39.0 & 22.5 & 25.0 & 17.3 & 7.7 & 1.8 & 2.2 & 1.5 \\
\hline Other Asia & 41.8 & 40.1 & 32.8 & 22.7 & 18.2 & 12.3 & 1.9 & 2.2 & 2.1 \\
\hline
\end{tabular}

Source: United Nations, Department of International Economic and Social Affairs, World population prospects as assessed in 1984(printout).

\footnotetext{
${ }^{5}$ Birdsall, N., (1988), Handbook of development economics ,Volume 1, edited by T.N.Srinivasan
} 
Since 1950's population growth in developing countries has been around 2.0. Most of the Balkan countries belong to this group except Greece that is advanced economy according to IMF and Slovenia (developing country before 2007). In the developed economies since 1950 's we have population growth slowdown to 0.6 in the end of 1980's. In the regions Africa has achieved growth in population, Latin America had declined in population growth, and Other than East Asia the other parts of Asia had increased population growth to 2.1 in the end of 1980's. The population growth rate for the developing countries as well for the world, is predicted to decline towards zero rate bringing population stabilization in the twentieth second century ${ }^{6}$.Even with population growth rate decline size of population in the developing countries will continue to rise, and world population to reach 10 billion before 2050. For the next few decades the variance of prediction is small, so we cannot be sure about the precision of these demographic predictions. Industrial countries according to some projections will increase their population for $20 \%$ by 2050 , and developing countries will double their population by 2050. Assaf Razin and Uri Ben-Zion(1993) have outlined intergenerational model of population .Population was included in social utility function and assumption was made that preferences are same for each generation:

$$
V=\sum_{t=0}^{\infty} \beta^{t} U\left(c_{t}, \lambda_{t}\right)
$$

Here $\beta$ is the subjective factor by which current generation discounts utility of the next generation. The inclusion of population growth in the social utility function has also an empirical implication for the measurement of welfare improvement. That is, growth of per capita income, by itself, is an inappropriate measure of welfare improvement, and as a measure it is biased against countries with a high rate of population growth. The decision problem for current generation can be written as :

$$
\begin{gathered}
\left.V\left(k_{0}\right)=\max \left\{\sum_{t=0}^{\infty} \beta^{t} U\left(c_{t}, \lambda_{t}\right)\right)\right\} \\
0 \leq c_{t} \leq k_{t} \\
0 \leq \lambda \leq \bar{\lambda}
\end{gathered}
$$

\footnotetext{
${ }^{6}$ Based on the population projections by World Bank
} 
$\mathrm{K}_{\mathrm{t}}$ is the capital for the current generation; $\lambda_{\mathrm{t}}$ is the current level of population growth $\bar{\lambda}$ is the maximum feasible level of population growth. Marginal utilities are positive and diminishing. $c_{t}$ is per capita life time consumption. Following decision is presented partially derived:

$$
\begin{aligned}
& \frac{\partial U}{\partial \lambda}\left(c_{t}, \lambda_{t}\right)=\frac{\beta}{\lambda_{t}} k_{t+1} \frac{\partial U}{\partial c}\left(c_{t+1}, \lambda_{t+1}\right) \\
& \frac{\partial U}{\partial \lambda}\left(c_{t}, \lambda_{t}\right)=\frac{\beta}{\lambda_{t}} \frac{\partial f}{\partial k}\left(k_{t}-c_{t}\right) \frac{\partial U}{\partial c}\left(c_{t+1}, \lambda_{t+1}\right)
\end{aligned}
$$

Equation (4) may be interpreted as describing the optimum decision with respect to the level of population growth $\lambda_{t}$ On the one hand an extra unit of $\lambda_{t}$ will increase welfare by the marginal utility of population growth, the left-hand side of (4). In the second equation the level of capital is decreased by the consumption of the current generation. And this equation (5) describes the optimal level of consumption.

According to $\underline{\text { Ramsey }(1928)^{7}}$, optimal rate of consumption is:

$$
u(c)=\frac{d U(c)}{d c}
$$

In the equilibrium there will be no saving and

$$
\frac{d c}{d t}=\frac{d k}{d t}=0
$$

Marginal productivity of capital is :

$$
\frac{\partial f}{\partial k}=\rho \quad 8
$$

If we take into account intergenerational differences in tastes we get:

$$
\begin{gathered}
U\left(c_{0}, \lambda_{0}\right)=a \log c_{0}+v\left(\lambda_{0}\right) \\
U\left(c_{t}, \lambda_{t}\right)=a \log c_{t}+v\left(\lambda_{t}, \theta\right), t \geq 1
\end{gathered}
$$

Here $\square$ is parameter in the function $\mathrm{v}$ which distinguishes the utility of future generations, derived from population increase, from that of the parents generation .If we include uncertainty in the population growth we get :

\footnotetext{
${ }^{7}$ Ramsey,F.,P.(1928), A Mathematical theory of saving, The Economic journal Vol.38 No.152

${ }^{8} \rho$ is the rate of discounting if $\frac{\partial f}{\partial k}>\rho$ there will be saving, or investment $\frac{\partial f}{\partial k}<\rho$
} 


$$
\begin{gathered}
\left.V\left(k_{0}\right)=E\left\{\sum_{t=0}^{\infty} \beta^{t} U\left(c_{t}, \lambda_{t}\right)\right)\right\} \\
0 \leq c_{t} \leq k_{t} \\
0 \leq h_{t} \leq \bar{h}
\end{gathered}
$$

Here $\mathrm{E}$ is the expected value of the population growth, expectation operator. Consumption should be greater than zero, and less than total capital of the current generation, and $h_{t}$ is the variable by which population change is controlled.

\section{Empirical part}

\section{Econometric Methodology}

Data in this paper are gathered from Penn world Table ${ }^{9}$. Data cover period from 1950 to 2009 for 10 Balkan countries: Albania, Bosnia and Herzegovina, Bulgaria, Croatia, Greece, Macedonia, Romania, Serbia, Slovenia, Turkey. These are 10 panels 60 observations per panel. But the data set has gaps on average we have 59,6 observations per group, so in 10 panels we have around 596 observations. Mostly data are missing for the GDPPPP (GDP in PPP terms) for the period 1950 to 1969 this is due to lack of data collection by the statistical bureaus in this countries for this period.

These data are pooled cross-section time series or panel data. Pooled data are characterized by having repeated observations (most frequently years) on fixed units (most frequently states and nations). This means that pooled arrays of data are one that combines cross-sectional data on $\mathrm{N}$ spatial units and $\mathrm{T}$ time periods to produce a data set of $N \times T$ observations (Podestà,2002). However, when the cross-section units are more numerous than temporal units $(\mathrm{N}>\mathrm{T})$, the pool is often conceptualized as a "cross-sectional dominant". conversely, when the temporal units are more numerous than spatial units $(\mathrm{T}>\mathrm{N})$, the pool is called "temporal dominant" (Stimson 1985). The generic pooled linear regression model estimable by Ordinary Least Squares (OLS) procedure is given by the following equation:

$$
\begin{gathered}
y_{i t}=\beta_{1}+\sum_{k=2}^{k} \beta_{k} x_{k i t}+e_{i t} \\
\Delta y_{i}=\delta_{0}+\beta_{1} \Delta x_{i}+\Delta u_{i}
\end{gathered}
$$

where " $\Delta$ " denotes the change from $t=1$ to $t=2$. The unobserved effect, $a_{i}$, does not appear in (2): it has been "differenced away." Also, the intercept in (2) is actually

\footnotetext{
${ }^{9}$ http://pwt.econ.upenn.edu/php site/pwt70/pwt70 form.php Alan Heston, Robert Summers and Bettina Aten, Penn World Table Version 7.0, Center for International Comparisons of Production, Income and Prices at the University of Pennsylvania, May 2011.
} 
the change in the intercept from $t=1$ to $t=2$.Equation (2) is simple first differenced pooled cross section regression where each variable is differenced over time. After we apply OLS estimation we will run fixed effects and random effects model

Static two way fixed effect model:

$$
\begin{gathered}
y_{i t}=\alpha_{i}+\delta_{i} t+\rho y_{t-1}+\theta_{t}+e_{i t} \\
i=1, \ldots N \quad t=1, \ldots T
\end{gathered}
$$

1. $\alpha_{i}$ unit-specific characteristics

2. $\gamma_{i}$ unit-specific deterministic trend parameters

3. $\mu_{t}$ time-specific effects (common to all units)

4. $\beta$ is common to all units

Next random effects model also is going to be applied. If you have reason to believe that differences across entities have some influence on your dependent variable then you should use random effects.

The random effects model is :

$$
Y_{i t}=\beta X_{i t}+\alpha+u_{i t}+\varepsilon_{i t}
$$

$\mathrm{u}_{\mathrm{it}}$ is between entity error, $\varepsilon_{i t}$ is within entity error.

Unobserved model becomes random effects model when we assume that unobserved effect $\alpha$ is uncorrelated with each explanatory variable:

$$
\operatorname{cov}\left(x_{i t j}, \alpha_{i}\right)=0, t=1,2 \ldots \ldots . T ; j=1,2, \ldots, K
$$

If we define composition error term $v_{i t}=\alpha_{i}+u_{i t}$ :

$$
y_{i t}=\beta_{0}+\beta_{1} x_{i t 1}+\ldots .+\beta_{k} x_{i t k}+v_{i t}
$$

Im, Pesaran and Shin (JE 2003) propose a test based on the average of a augmented DickeyFuller tests computed for each panel unit in the model

$$
y_{i t}=\alpha_{i}+\delta_{i} t+\rho y_{i t-1}+\theta_{t}+e_{i t}
$$

where $e_{i t}$ can be:

Serially correlated

$>$ and heteroscedastic

$>$ but cross-sectional independent apart from the presence of the common time effects $\theta_{t}$.

The estimating equation is :

$$
\Delta y_{i t}=\phi_{i} y_{i t-1}+\sum_{k=1}^{K_{I}} \not k i \Delta y_{i t-k}+\varepsilon_{i t}
$$


The null hypothesis of a unit root is tested using $t_{b a r}=\frac{1}{N} \sum{ }_{i=1}^{N} t \phi i$

$H_{0}: \phi=0$

against the heterogeneous alternative:

$$
H_{1}:\left\{\begin{array}{c}
\phi<0 \text { for } i=1, \ldots . N_{1} \\
\phi=0 \text { for } i=N_{1}+1, \ldots . N
\end{array}\right.
$$

In the panel unit root test in the general model, let us first look at the test $H_{0}=\rho=1$

$\mathrm{H}_{0}$ : unit root Different $\mathrm{H}_{1}$ specifications have been proposed for the model:

$$
\begin{gathered}
y_{i t}=\alpha_{i}+\delta_{i} t+\rho y_{i t-1}+\delta_{i} \theta_{t}+\varepsilon_{i t} \\
H_{1}:\left\{\begin{array}{c}
\rho<1 \text { for all } i \\
\rho=1 \text { for } i=N_{1}+1, \ldots . N
\end{array}\right.
\end{gathered}
$$

\section{Data}

To estimate the following model we define the following set of variables:

Table 1 Variable definitions

\begin{tabular}{|l|l|}
\hline Variable & Definition \\
\hline lgdpgro & $\begin{array}{l}\text { Logarithm of growth of GDP per capita PPP } \\
\text { converted at 2005 constant prices }\end{array}$ \\
\hline lpopgro & $\begin{array}{l}\text { Log of growth rate of population in thou- } \\
\text { sands }\end{array}$ \\
\hline
\end{tabular}

\section{Descriptive statistics of the model}

In the descriptive statistics we report the usual number of observations per variable, means, standard deviations, and minimums and maximums. The descriptive statistics of our model for ten countries is given below in a Table 2 .

Table 2 Descriptive statistics of the model

\begin{tabular}{|l|l|l|l|l|l|}
\hline Variable & Obs. & Mean & Std.deviation & Min & Max \\
\hline lgdpgro & 342 & 384.5786 & 98.82886 & -100 & 481.413 \\
\hline lpopgro & 596 & 770.1818 & 101.867 & 611.0394 & 1024.904 \\
\hline
\end{tabular}


For the table of the descriptive statistics of the model we can see that the mean of log of population growth is 770.1818 (thousands), minimum is 611.0394(thousands) while the maximum of this variable is 1024.904(1 million and 24 thousands and 904). Visually from the next graph we can see that lgdpgro and lpopgro are positively correlated. On this plot we use acronyms for the 10 countries (Albania-A, Bosnia and Herzegovina-B, Bulgaria-BG, Croatia-C, Greece-G, Macedonia-M, Romania-R, Serbia-S, Slovenia-SV, Turkey-T).

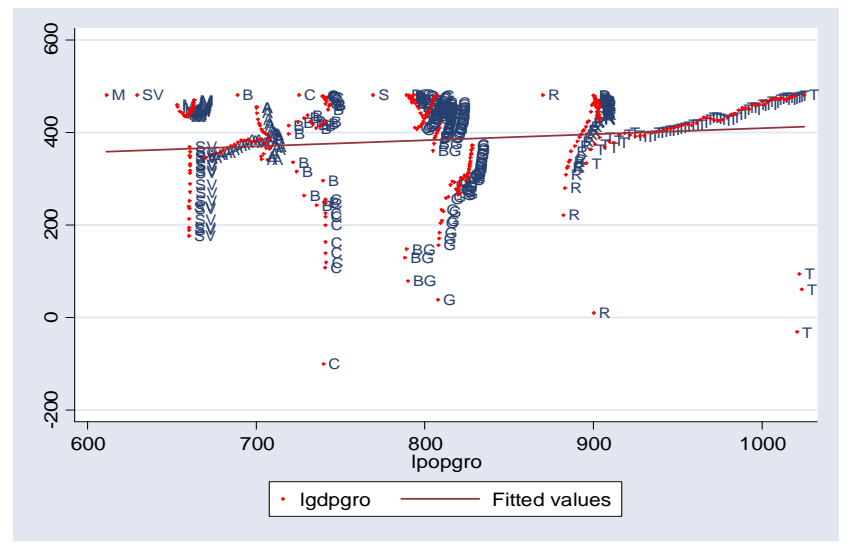

From the graph we can see that substantial part of the observations is below the trend in logarithm of the GDP per capita growth and Turkey has highest population growth from the sample countries while Macedonia some of the lowest, and Croatia and Turkey have experienced negative GDP growth rates. When we try to investigate heterogeneity across countries or entities we do so by creating scatter two way for population growth and country. The resulting scatter from our data I given on the next page. There countries are numbered: 1.Albania 2. Bosnia and Herzegovina, 3.Bulgaria,4. Croatia, 5.Greece,6. Macedonia,7. Romania,8.Serbia, 9.Slovenia, 10. Turkey.

\section{Scatter: Fixed effects: Heterogeneity across countries (or entities)}

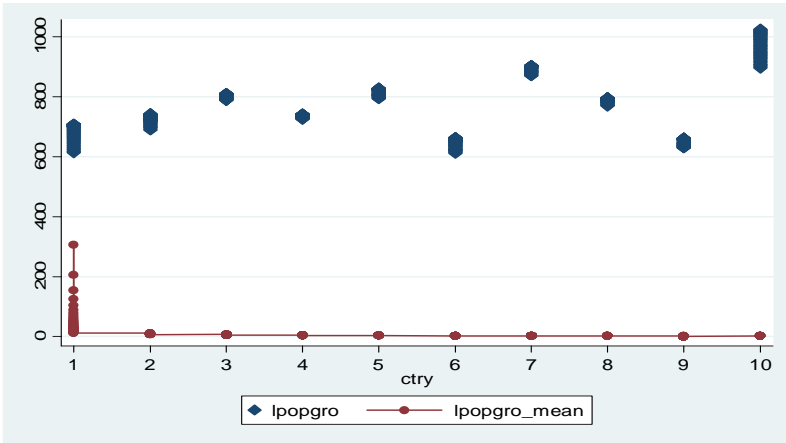

On the scatter is presented logarithm of population growth mean for the 10 countries. Turkey has highest population growth, while Macedonia lowest in the region, together with Slovenia 
that has little higher growth of population. Log of population growth across Balkan countries si given in the following table of graphs 3

\section{Table of graphs 3}

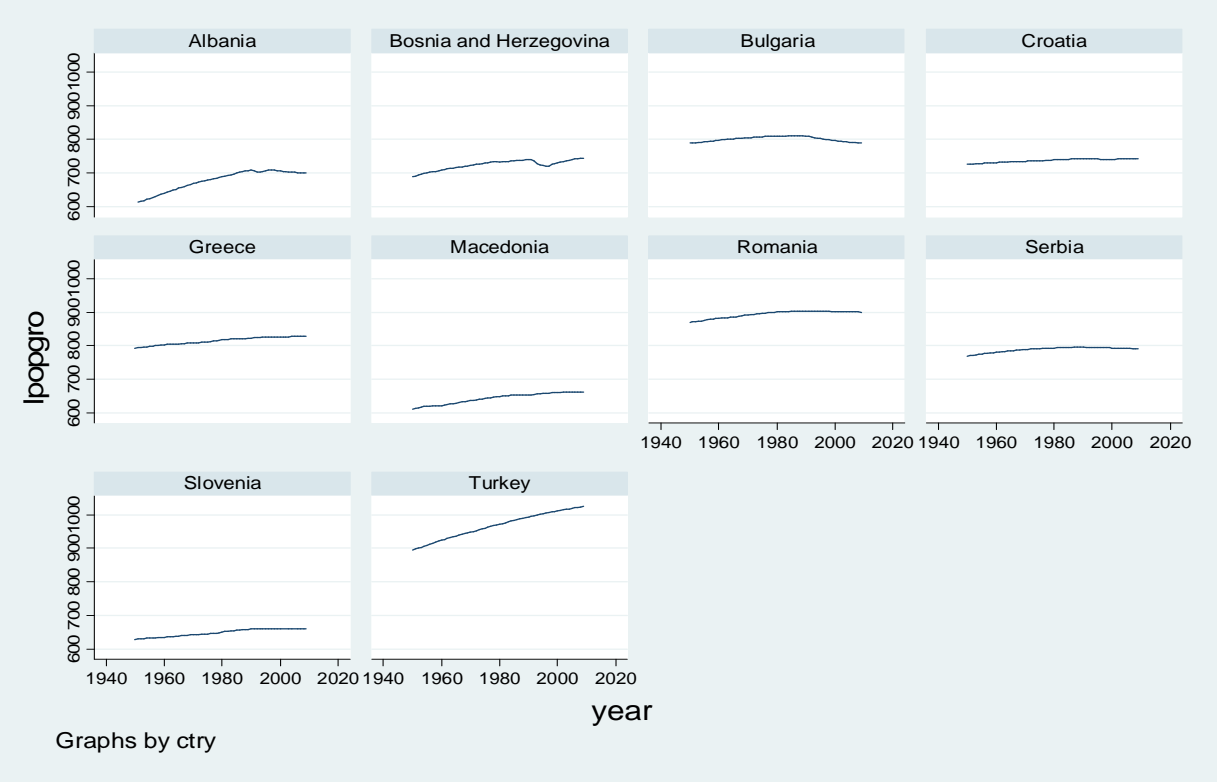

We can create a Table of graphs even for log of GDP per capita growth Table of graphs 4

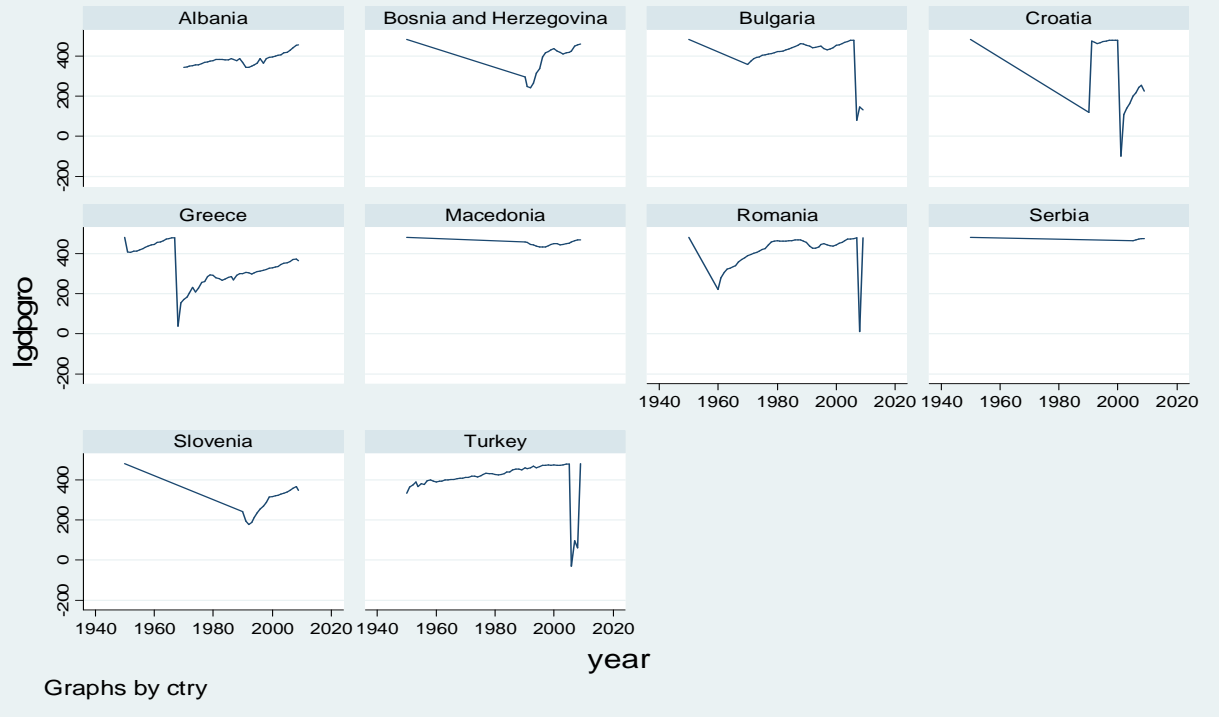

From the scatter we can see that countries like Croatia, Bulgaria, Turkey, Romania have suffered from the economic and financial crisis circa 2007-2008, with a sharp decline in the log of growth of GDP variable. 


\section{Least squares dummy variable model (LSDV)}

There are several strategies for estimating fixed effect models. The least squares dummy variable model (LSDV) uses dummy variables, whereas the within effect does not. These strategies produce the identical slopes of non-dummy independent variables. The between effect model also does not use dummies, but produces different parameter estimates. There are pros and cons of these strategies. These are presented in the following table

\section{Table 5 Pros and cons of different ways of estimating fixed effects model ${ }^{10}$}

\begin{tabular}{|c|c|c|c|}
\hline & LSDV1 & Within effect & Between effect \\
\hline Functional form & $y_{i}=i \alpha_{i}+X_{i} \beta+\varepsilon_{i}$ & $y_{i t}-\bar{y}_{i n}=x_{i t}-\bar{x}_{i n}+\varepsilon_{i t}-\bar{\varepsilon}_{i n}$ & $\bar{y}_{i n}=\alpha+\bar{x}_{i n}+\varepsilon_{i}$ \\
\hline Dummy & Yes & No & No \\
\hline Dummy coefficient & Presented & Need to be computed & N/A \\
\hline Transformation & No & Deviation from the group means & Group means \\
\hline Intercept & Yes & No & No \\
\hline $\mathrm{R}^{2}$ & Correct & Incorrect & \\
\hline SSE & Correct & Correct & \\
\hline MSE & Correct & Smaller & \\
\hline Standard error of $\beta$ & Correct & Incorrect(smaller) & \\
\hline $\mathrm{DF}_{\text {error }}$ & nT-n-k & nT-n-k(Larger) & $\mathrm{n}-\mathrm{K}$ \\
\hline Observations & nT & nT & $\mathrm{n}$ \\
\hline
\end{tabular}

\section{Testing for group effects}

The null hypothesis is that all dummy parameters except one are zero:

$$
H_{0}: \mu_{1}=\ldots=\mu_{n-1}=0
$$

This hypothesis is tested by the F test (Greene ,2008) $^{11}$, which is based on loss of goodnessof-fit. The robust model in the following formula is LSDV and the efficient model is the pooled regression.

$$
F(n-1, n T-n-K)=\frac{\left(R_{L S D V}^{2}-R_{P o o l e d}^{2}\right) /(n-1)}{\left(1-R_{L S D V}^{2}\right) /(n T-n-K)}
$$

\footnotetext{
${ }^{10}$ Source: Indiana University Stath/Math center

${ }^{11}$ Greene,H.W.,(2008), Econometric Analysis, Prentice Hall
} 
Here $T=$ total number of temporal observations. $n=$ the number of groups, and $k=$ number of regressors in the model. If we find significant improvements in the $\mathrm{R}^{2}$, then we have statistically significant group effects.

In Greene (2008) this model in matrix notation is presented as:

$$
y=\left[\begin{array}{lll}
x & d_{1} & d_{2} \ldots \ldots . . d_{n}
\end{array}\right]\left[\begin{array}{l}
b \\
a
\end{array}\right]+\varepsilon
$$

With assembling all $\mathrm{nT}$ rows gives:

$$
y=X \beta+D \alpha+\varepsilon
$$

\begin{tabular}{|c|c|c|c|}
\hline $\begin{array}{l}\text { Dependent varia- } \\
\text { ble: lgdpgro }\end{array}$ & $\begin{array}{l}\text { Logarithm of } \\
\text { growth of } \\
\text { GDP per capi- } \\
\text { ta PPP }\end{array}$ & $\begin{array}{c}\text { Ordinary least } \\
\text { squares }\end{array}$ & $\begin{array}{c}\text { Ordinary least } \\
\text { squares with } \\
\text { dummies }\end{array}$ \\
\hline variables & & OLS & OLS_dum \\
\hline lpopgro & $\begin{array}{l}\text { Log of growth } \\
\text { rate of popula- } \\
\text { tion }\end{array}$ & $0.13 *$ & 0.06 \\
\hline _Icountry_2 & $\begin{array}{l}\text { Bosnia and } \\
\text { Herzegovina }\end{array}$ & & 4.81 \\
\hline _Icountry_3 & Bulgaria & & 23.99 \\
\hline _Icountry_4 & Croatia & & $-61.16^{*}$ \\
\hline _Icountry_5 & Greece & & -55.76 \\
\hline _Icountry_6 & Macedonia & & $71.53 * *$ \\
\hline _Icountry_7 & Romania & & 22.48 \\
\hline _Icountry_8 & Serbia & & 86.1 \\
\hline _Icountry_9 & Slovenia & & $-87.8 * *$ \\
\hline _Icountry_10 & Turkey & & 10.79 \\
\hline _cons & Constant & $280.31 * * *$ & 341.85 \\
\hline $\mathrm{N}$ & & 339 & 339 \\
\hline $\begin{array}{l}\text { F-statistics } \\
(1,337)\end{array}$ & & & $8.40^{* * * *}$ \\
\hline
\end{tabular}

Table 6 OLS regression and OLS with dummies (Appendix 2) ${ }^{12}$

legend: $* \mathrm{p}<0.05 ; * * \mathrm{p}<0.01 ; * * * \mathrm{p}<0.001$

This OLS model shows that on average in these 10 Balkan countries if the population increases by $1 \%$ GDP in these 10 countries will rise by 0.13 percent. This coefficient is signifi- 
cant at $1 \%$ level of significance. Dummy variables take values from [0,1],zero if the country is not included in the regression and 1 if the country is in the regression. Dummies for Croatia, Macedonia, and Slovenia are significant at 1\%,5\%, and $10 \%$ levels of significance. So for instance coefficient on Macedonia is highest significant coefficient meaning if we control for Macedonia we will on average find more positive association between growth of GDP and population growth. If we include Croatia and Slovenia in the regression growth of population would have been growth detrimental. If Serbia was in the regression we would have on average found more positive association between growth of GDP and population growth, but typically if we control for Serbia in the regression t-statistics will report 0.10 lower. Fstatistics is significant at all levels of conventional significance; this means that we can reject $\mathrm{H}_{0}$ : jointly insignificant dummy variables in favor of the alternative jointly significant dummy variables. By adding the dummy for each country we are estimating the pure effect of lpopgro (by controlling for the unobserved heterogeneity)

\section{Fixed effects model ${ }^{13}$}

". . . The fixed-effects model controls for all time-invariant differences between the individuals, so the estimated coefficients of the fixed-effects models cannot be biased because of omitted time-invariant characteristics...[like culture,religion, gender, race, etc]"

To see if time fixed effects are needed when running fixed effect model we will use a joint test to see if the dummies for all years are equal to zero.

The linear regression model with fixed effects is

$$
\begin{gathered}
y_{i t}=\boldsymbol{\beta}^{\prime} \mathbf{x}_{i t}+\alpha_{i}+\delta_{t}+\varepsilon_{i t}, t=1, \ldots, T(i), i=1, \ldots, N, \\
E\left[\varepsilon_{i t} \mid \mathbf{x}_{i 1}, \mathbf{x}_{i 2}, \ldots, \mathbf{x}_{i T(i)}\right]=0, \\
\operatorname{Var}\left[\varepsilon_{i t} \mid \mathbf{x}_{i 1}, \mathbf{x}_{i 2}, \ldots, \mathbf{x}_{i T(i)}\right]=\sigma^{2} .
\end{gathered}
$$

We have assumed the strictly exogenous regressors case in the conditional moments, [see Woolridge (1995)]. We have not assumed equal sized groups in the panel. The vector $\beta$ is a

\footnotetext{
${ }^{13}$ Greene, W.(2001), Estimating Econometric Models with Fixed Effects, Department of Economics, Stern School of Business, New York University,
} 
set of parameters of primary interest, $\alpha_{i}$ is the group specific heterogeneity. We have included time specific effects but, they are only tangential in what follows. Since the number of periods is usually fairly small, these can usually be accommodated simply by adding a set of time specific dummy variables to the model. Our interest here is in the case in which $N$ is too large to do likewise for the group effects. For example in analyzing census based data sets, $N$ might number in the tens of thousands. The analysis of two way models, both fixed and random effects, has been well worked out in the linear case [See, e.g., Baltagi (1995) and Baltagi, et al. (2005).]. A full extension to the nonlinear models considered in this paper remains for further research The parameters of the linear model with fixed individual effects can be estimated by the 'least squares dummy variable' (LSDV) or 'within groups' estimator, which we denote $\mathbf{b}_{L S D V}$. This is computed by least squares regression of $y_{i t} *=\left(y_{i t}-\bar{y}_{i .}\right)$ on the same transformation of $\mathbf{x}_{i t}$ where the averages are group specific means. The individual specific dummy variable coefficients can be estimated using group specific averages of residuals. [See, e.g., Greene (2000, Chapter 14).] The slope parameters can also be estimated using simple first differences. Under the assumptions, $\mathbf{b}_{L S D V}$ is a consistent estimator of $\boldsymbol{\beta}$. However, the individual effects, $\alpha_{i}$, are each estimated with the $T(i)$ group specific observations. Since $T(i)$ might be small, and is, moreover, fixed, the estimator, $a_{i, L S D V}$, is inconsistent. But, the inconsistency of $a_{i, L S D V}$, is not transmitted to $\mathbf{b}_{L S D V}$ because $\bar{y}_{i}$ is a sufficient statistic. The LSDV estimator $\mathbf{b}_{L S D V}$ is not a function of $a_{i, L S D V}$. There are a few nonlinear models in which a like result appears.

We will define a nonlinear model by the density for an observed random variable, $y_{i t}$,

$$
f\left(y_{i t} \mid \mathbf{x}_{i 1}, \mathbf{x}_{i 2}, \ldots, \mathbf{x}_{i T(i)}\right)=g\left(y_{i t}, \boldsymbol{\beta}^{\prime} \mathbf{x}_{i t}+\alpha_{i}, \boldsymbol{\theta}\right)
$$

where $\theta$ is a vector of ancillary parameters such as a scale parameter, an overdispersion parameter in the Poisson model or the threshold parameters in an ordered probit model. We have narrowed our focus to linear index function models. For the present, we also rule out dynamic effects; $y_{i, t-1}$ does not appear on the right hand side of the equation. [See, e.g., Arellano and Bond (1991), Arellano and Bover (1995), Ahn and Schmidt (1995), Orme (1999), Heckman and MaCurdy (1980)]. However, it does appear that extension of the fixed effects model to dynamic models may well be practical. This, and multiple equation models, such as VAR's are left for later extensions. [See Holtz-Eakin (1988) and Holtz-Eakin, Newey and Rosen $(1988,1989)$.$] Lastly, note that only the current data appear directly in the density for$ 
the current $y_{i t}$. We will also be limiting attention to parametric approaches to modeling. The density is assumed to be fully defined.

Many of the models we have studied involve an ancillary parameter vector, $\theta$. No generality is gained by treating $\boldsymbol{\theta}$ separately from $\boldsymbol{\beta}$, so at this point, we will simply group them in the single parameter vector $\boldsymbol{\gamma}=\left[\boldsymbol{\beta}^{\prime}, \boldsymbol{\theta}^{\prime}\right]^{\prime}$. Denote the gradient of the log likelihood by

$$
\begin{aligned}
& \mathbf{g}_{\gamma} \quad=\frac{\partial \log L}{\partial \boldsymbol{\gamma}}=\sum_{i=1}^{N} \sum_{t=1}^{T(i)} \frac{\partial \log g\left(y_{i t}, \boldsymbol{\gamma}, \mathrm{x}_{i t}, \alpha_{i}\right)}{\partial \boldsymbol{\gamma}} \text { (a } K_{\gamma} \times 1 \text { vector) } \\
& g_{\alpha \mathrm{i}} \quad=\frac{\partial \log L}{\partial \alpha_{i}}=\sum_{t=1}^{T(i)} \frac{\partial \log g\left(y_{i t}, \boldsymbol{\gamma}, \mathbf{x}_{i t}, \alpha_{i}\right)}{\partial \alpha_{i}} \text { (a scalar) } \\
& \mathbf{g}_{\alpha} \quad=\left[g_{\alpha 1}, \ldots, g_{\alpha N}\right]^{\prime} \text { (an } N \times 1 \text { vector) } \\
& \mathbf{g} \quad=\left[\mathbf{g}_{\gamma}{ }^{\prime}, \mathbf{g}_{\alpha}{ }^{\prime}\right]^{\prime}\left(\mathrm{a}\left(K_{\gamma}+N\right) \times 1 \text { vector }\right) .
\end{aligned}
$$

The full $\left(K_{\gamma}+N\right) \times\left(K_{\gamma}+N\right)$ Hessian is

$$
\mathbf{H}=\left[\begin{array}{c:cccc}
\mathrm{H}_{\gamma} & \mathrm{h}_{\gamma 1} & \mathrm{~h}_{\gamma 2} & \cdots & \mathrm{h}_{\gamma N} \\
\mathrm{~h}_{\gamma 1}{ }^{\prime} & h_{11} & 0 & \cdots & 0 \\
\mathrm{~h}_{\gamma 2}{ }^{\prime} & 0 & h_{22} & \cdots & 0 \\
\vdots & \vdots & \vdots & \ddots & 0 \\
\mathrm{~h}_{\gamma N}{ }^{\prime} & 0 & 0 & 0 & h_{N N}
\end{array}\right]
$$

\section{Estimating the Fixed Effects Model}

We could just include dummy variables for all but one of the units. This "sweeps out the unit effects" because when you mean deviate variables, you no longer need to include an intercept term. So the model regresses $\mathrm{y}_{\mathrm{i}, \mathrm{t}}-$ mean $\left(\mathrm{y}_{\mathrm{i}}\right)$ on $\mathrm{x}_{\mathrm{i}, \mathrm{t}}-$ mean $\left(\mathrm{x}_{\mathrm{i}}\right)$. This is often called this "within" estimator because it looks at how changes in the explanatory variables cause y to vary around a mean within the unit.

\section{Random Effects models}

Instead of thinking of each unit as having its own systematic baseline, we think of each intercept as the result of a random deviation from some mean intercept. If we have a large $\mathrm{N}$ (panel data), we will be able to do this, and random effects will be more efficient than fixed effects. It has $\mathrm{N}$ more degrees of freedom, and it also uses information from the "between" 
estimator (which averages observations over a unit and regresses average $\mathrm{y}$ on average $\mathrm{x}$ to look at differences across units). If we have a big T (TS-CS data), then the difference between fixed effects and random effects, goes away.

$$
\mathrm{y}_{\mathrm{i}, \mathrm{t}}=\mu+\alpha_{\mathrm{i}}+\mathrm{x}_{\mathrm{i}, \mathrm{t}} \beta+\mathrm{e}_{\mathrm{i}, \mathrm{t}}
$$

Table 7 Distinguishing between random effects and fixed effects model ${ }^{14}$

\begin{tabular}{|c|c|}
\hline $\begin{array}{l}\text { Random vs. } \\
\text { Fixed }\end{array}$ & Definition \\
\hline Variables & $\begin{array}{l}\text { Random variable: (1) is assumed to be measured with measurement error. The scores are a } \\
\text { function of a true score and random error; (2) the values come from and are intended to gene- } \\
\text { ralize to a much larger population of possible values with a certain probability distribution } \\
\text { (e.g., normal distribution); (3) the number of values in the study is small relative to the values } \\
\text { of the variable as it appears in the population it is drawn from. Fixed variable: (1) assumed to } \\
\text { be measured without measurement error; (2) desired generalization to population or other stu- } \\
\text { dies is to the same values; (3) the variable used in the study contains all or most of the varia- } \\
\text { ble's values in the population. } \\
\text { It is important to distinguish between a variable that is varying and a variable that is random. } \\
\text { A fixed variable can have different values, it is not necessarily invariant (equal) across groups. }\end{array}$ \\
\hline Effects & $\begin{array}{l}\text { Random effect: (1) different statistical model of regression or ANOVA model which assumes } \\
\text { that an independent variable is random; (2) generally used if the levels of the independent } \\
\text { variable are thought to be a small subset of the possible values which one wishes to generalize } \\
\text { to; (3) will probably produce larger standard errors (less powerful). Fixed effect: (1) statis- } \\
\text { tical model typically used in regression and ANOVA assuming independent variable is fixed; } \\
\text { (2) generalization of the results apply to similar values of independent variable in the popula- } \\
\text { tion or in other studies; (3) will probably produce smaller standard errors (more powerful). }\end{array}$ \\
\hline Coefficients & $\begin{array}{l}\text { Random coefficient: term applies only to MLR analyses in which intercepts, slopes, and va- } \\
\text { riances can be assumed to be random. MLR analyses most typically assume random coeffi- } \\
\text { cients. One can conceptualize the coefficients obtained from the level-1 regressions as a type } \\
\text { of random variable which comes from and generalizes to a distribution of possible values. } \\
\text { Groups are conceived of as a subset of the possible groups. } \\
\text { Fixed coefficient: a coefficient can be fixed to be non-varying (invariant) across groups by } \\
\text { setting its between group variance to zero. } \\
\text { Random coefficients must be variable across groups. Conceptually, fixed coefficients may be } \\
\text { invariant } \text { or varying across groups. }\end{array}$ \\
\hline
\end{tabular}

\section{Estimations of random and fixed effects model}

In the next Table we will present the results from the fixed and random effect regressions. We will perform a Hausman test. Here we mention that when we do this panel models and

\footnotetext{
${ }^{14}$ Newsom USP 656 Multilevel Regression Winter 2006
} 
regressions on our data independent variables are collinear with the panel variable ctry, so we use second panel variable year because we cannot run the regressions otherwise.

Table 8 Fixed effects model and random effects model (See Appendix 3 ) ${ }^{15}$

\begin{tabular}{|c|c|c|c|}
\hline $\begin{array}{c}\text { Dependent variable: } \\
\text { lgdpgro }\end{array}$ & $\begin{array}{l}\text { Logarithm of } \\
\text { growth of GDP } \\
\text { per capita PPP }\end{array}$ & $\begin{array}{c}\text { Fixed Effects } \\
\text { model }\end{array}$ & $\begin{array}{c}\text { Random Effects } \\
\text { model }\end{array}$ \\
\hline variables & & $\mathrm{FE}$ & $\mathrm{RE}$ \\
\hline lpopgro & $\begin{array}{l}\text { Log of growth } \\
\text { rate of popula- } \\
\text { tion }\end{array}$ & 0.76 & 0.28 \\
\hline _Iyear_1951 & Dummy 1951 & -40.99 & -56.28 \\
\hline _Iyear_1952 & Dummy 1952 & -37.999 & -52.399 \\
\hline _Iyear_1953 & Dummy 1953 & -29.76 & -43.268 \\
\hline _Iyear_1954 & Dummy 1954 & -41.07 & -53.69 \\
\hline Iyear_1955 & Dummy 1955 & -33.03 & -44.74 \\
\hline Iyear_1956 & Dummy 1956 & -34.37 & -45.16 \\
\hline _Iyear_1957 & Dummy 1957 & -22.94 & -32.79 \\
\hline _Iyear_1958 & Dummy 1958 & -19.70 & -28.55 \\
\hline _Iyear_1959 & Dummy 1959 & -20.83 & -28.67 \\
\hline _Iyear_1960 & Dummy 1960 & -109.62 & -112.96 \\
\hline _Iyear_1961 & Dummy 1961 & -87.74 & -90.35 \\
\hline _Iyear_1962 & Dummy 1962 & -77.88 & -79.88 \\
\hline _Iyear_1963 & Dummy 1963 & -68.69 & -70.14 \\
\hline ............ & $\ldots \ldots \ldots$ & .......... & $\ldots \ldots \ldots$ \\
\hline _Iyear_2007 & Dummy 2007 & $-149.48174 * * *$ & $-130.11 * *$ \\
\hline _Iyear_2008 & Dummy 2008 & $-188.25289 * * *$ & $-168.84 * * *$ \\
\hline _Iyear_2009 & Dummy 2009 & $-106.23162 *$ & $-86.79 *$ \\
\hline _cons & Constant & -132.74 & 256.91 \\
\hline $\mathrm{N}$ & & 339 & 339 \\
\hline
\end{tabular}

In the time fixed effects model lpopgro is statistically significant $t=1,75$ at $10 \%$ level of significance, the coefficient is positive 0.76 , meaning that $1 \%$ increase in growth of population will induce GDP growth of $0.76 \%$. This variable in RE model has not got significant coefficient. We set years as number of dummies here. We set null hypothesis here that all dummies are equal to zero and we test with F statistics. Probability exceeding F statistics is $0,8507^{16}$

\footnotetext{
${ }^{15}$ See Appendix 3 Panel estimation techniques

${ }^{16}$ See Appendix 3 testparm
} 
this means that we cannot reject the null that all years coefficients are zero, therefore no time fixed effects are needed. Hausman test is in favor of Fixed effects model i.e. difference in coefficients is not systematic. Probability $>$ chi2 $=1.000^{17}$. Coefficients for the years 2007.2008 and 2009 are highly significant but more negative than other years this is due to financial crisis if we controlled only for these three years on average we will get less positive association between GDP growth and population growth.

\section{Panel unit root tests $\underline{(\text { See Appendix 4) }}$}

“xtunitroot performs a variety of tests for unit roots (or stationarity) in panel datasets. The Levin-Lin-Chu (2002), Harris-Tzavalis (1999), Breitung (2000; Breitung and Das 2005), ImPesaran-Shin (2003), and Fisher-type (Choi 2001) tests have as the null hypothesis that all the panels contain a unit root. The Hadri (2000) Lagrange multiplier (LM) test has as the null hypothesis that all the panels are (trend) stationary. The top of the output for each test makes explicit the null and alternative hypotheses. Options allow you to include panelspecific means (fixed effects) and time trends in the model of the data-generating process"

$\mathrm{xtfisher}$ combines the $\mathrm{p}$-values from $\mathrm{N}$ independent unit root tests, as developed by Maddala and $\mathrm{Wu}(1999)$. Based on the p-values of individual unit root tests, Fisher's test assumes that all series are non-stationary under the null hypothesis against the alternative that at least one series in the panel is stationary. Unlike the Im-Pesaran-Shin (1997) test (ipshin or xtunitroot ips), Fisher's test does not require a balanced panel. This test is based on augmented DickeyFuller tests.

Table 9 Panel Unit root tests Variable gdpgro (Growth of GDP)

Ho: All panels contain unit roots

Ha: At least one panel is stationary

\begin{tabular}{|c|c|c|c|}
\hline Type of statistic & statistic & p-value & Decision \\
\hline Inverse chi-squared(20) $\mathrm{P}$ & 49.1548 & 0.0003 & $\begin{array}{l}\text { Sufficient evidence to } \\
\text { accept } \mathrm{H}_{\mathrm{A}}\end{array}$ \\
\hline Inverse normal & -3.8714 & 0.0001 & $\begin{array}{l}\text { Sufficient evidence to } \\
\text { accept } \mathrm{H}_{\mathrm{A}}\end{array}$ \\
\hline Inverse logit t(49) & -4.0690 & 0.0001 & $\begin{array}{l}\text { Sufficient evidence to } \\
\text { accept } \mathrm{H}_{\mathrm{A}}\end{array}$ \\
\hline $\begin{array}{l}\text { Modified inv. chi-squared } \\
\text { Pm }\end{array}$ & 4.6098 & 0.0000 & $\begin{array}{l}\text { Sufficient evidence to } \\
\text { accept } \mathrm{H}_{\mathrm{A}}\end{array}$ \\
\hline
\end{tabular}

\footnotetext{
${ }^{17}$ See Appendix 3 Hausman test

${ }^{18}$ Source Stata manual
} 
So we reject the null hypothesis that panels contain unit root and we accept the alternative that at least one panel is stationary.

Table 10 Panel Unit root tests Variable popgro (population growth)

Ho: All panels contain unit roots

Ha: At least one panel is stationary

\begin{tabular}{|c|c|c|c|}
\hline Type of statistic & statistic & p-value & Decision \\
\hline Inverse chi-squared(20) $\mathrm{P}$ & 61.3497 & 0.0000 & $\begin{array}{l}\text { Sufficient evidence to } \\
\text { accept } \mathrm{H}_{\mathrm{A}}\end{array}$ \\
\hline Inverse normal & -4.5153 & 0.0000 & $\begin{array}{l}\text { Sufficient evidence to } \\
\text { accept } H_{A}\end{array}$ \\
\hline Inverse logit $\mathrm{t}(54)$ & -5.0274 & 0.0000 & $\begin{array}{l}\text { Sufficient evidence to } \\
\text { accept } H_{A}\end{array}$ \\
\hline Modified inv. chi-squared Pm & 6.5380 & 0.0000 & $\begin{array}{l}\text { Sufficient evidence to } \\
\text { accept } \mathrm{H}_{\mathrm{A}}\end{array}$ \\
\hline
\end{tabular}

So here also we reject the null hypothesis that panels contain unit root and we accept the alternative that at least one panel is stationary. In conclusion population growth and GDP growth are stationary.

Conclusion

This paper confirmed that for the Balkan countries also applies the rule of linear relationship between population growth and population, but also that demographic structure in the Balkan countries will be very old in the next decades. Optimal population growth depends on capital in the future period and future consumption. Turkey has highest population growth, while Macedonia lowest in the region, together with Slovenia that has little higher growth of population. In the OLS regression with dummies the coefficient on Macedonia, is highest significant coefficient meaning, if we control for Macedonia we will on average find more positive association between growth of GDP and population growth. Hausman test was in favor of FE model, but FE and RE model showed that there is positive coefficient between GDP growth and population growth. Coefficient in the FE model was statistically significant, which was not case in RE model. From the Fischer's panel unit root test we reject the null hypothesis that panels contain unit root and we accept the alternative that at least one panel is stationary, for the population growth and GDP growth. 
Appendix 1 Regression on population growth and level of population

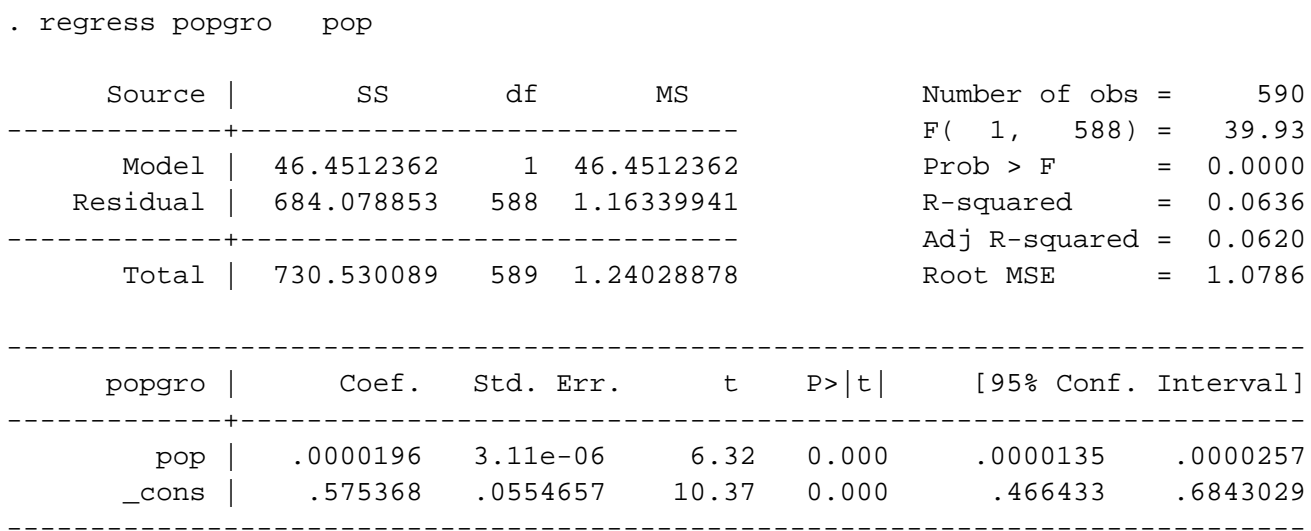

Appendix 2 OLS and OLS_dummies regression

\begin{tabular}{|c|c|c|}
\hline Variable | & ols & ols_dum \\
\hline lpopgro & $.12929031 *$ & .05814148 \\
\hline _Icountry_2 & & 4.8024968 \\
\hline Icountry_3 & & 23.983916 \\
\hline _Icountry_4 & & $-61.154368 *$ \\
\hline Icountry_5 & & -55.759953 \\
\hline _Icountry_6 & & $71.522809 * *$ \\
\hline _Icountry_7 & & 22.472556 \\
\hline _Icountry_8 & & 86.099647 \\
\hline _Icountry_9 & & $-87.803317 * *$ \\
\hline Icountry_10 & & 10.780687 \\
\hline _cons & $280.31333 * * *$ & 341.84296 \\
\hline $\mathrm{N}$ & 339 & 339 \\
\hline
\end{tabular}

. xi: regress lgdpgro lpopgro i.country

i.country _Icountry_1-10 (_Icountry_1 for coun $\sim \mathrm{y}==$ Albania omitted)

\begin{tabular}{r|rrr} 
Source | & SS & df & MS \\
Model | & 650078.81 & 10 & 65007.881 \\
Residual | & 2537279.52 & 328 & 7735.6083 \\
----------+---------1 & \\
Total | & 3187358.33 & 338 & 9430.05423
\end{tabular}

$\begin{array}{lr}\text { Number of obs } & =339 \\ \text { F(10, 328) } & 8.40 \\ \text { Prob }>\text { F } & =0.0000 \\ \text { R-squared } & =0.2040 \\ \text { Adj R-squared } & =0.1797 \\ \text { Root MSE } & =87.952\end{array}$

\begin{tabular}{|c|c|c|c|c|c|c|}
\hline lgdpgro | & Coef. & Std. Err. & t & $P>|t|$ & [95\% Conf. & Interval] \\
\hline lpopgro & .0581415 & .2607112 & 0.22 & 0.824 & -.4547355 & .5710185 \\
\hline
\end{tabular}




\begin{tabular}{|c|c|c|c|c|c|c|}
\hline _Icountry_2 & 4.802497 & 25.39018 & 0.19 & 0.850 & -45.14565 & 54.75064 \\
\hline _Icountry_3 & 23.98392 & 33.98436 & 0.71 & 0.481 & -42.87089 & 90.83872 \\
\hline _Icountry_4 & -61.15437 & 26.33497 & -2.32 & 0.021 & -112.9611 & -9.347613 \\
\hline _Icountry_5 & -55.75995 & 35.73427 & -1.56 & 0.120 & -126.0572 & 14.53731 \\
\hline -Icountry_6 & 71.52281 & 25.75835 & 2.78 & 0.006 & 20.85039 & 122.1952 \\
\hline _Icountry_7 & 22.47256 & 55.59951 & 0.40 & 0.686 & -86.90407 & 131.8492 \\
\hline -Icountry_8 & 86.09965 & 45.34624 & 1.90 & 0.058 & -3.10652 & 175.3058 \\
\hline -Icountry_9 & -87.80332 & 26.78825 & -3.28 & 0.001 & -140.5018 & -35.10485 \\
\hline Icountry_10 & 10.78069 & 73.11564 & 0.15 & 0.883 & -133.0541 & 154.6154 \\
\hline _cons & 341.843 & 181.9686 & 1.88 & 0.061 & -16.12976 & 699.8157 \\
\hline
\end{tabular}

\begin{tabular}{r|crr} 
Source & SS & df & \multicolumn{1}{c}{ MS } \\
Model & 61128.9658 & 1 & 61128.9658 \\
Residual & 3126229.37 & 337 & 9276.645 \\
-----------+----------- & \\
Total & 3187358.33 & 338 & 9430.05423
\end{tabular}

$\begin{array}{llr}\text { Number of obs } & = & 339 \\ \text { F }(1,337) & = & 6.59 \\ \text { Prob }>\text { F } & =0.0107 \\ \text { R-squared } & 0.0192 \\ \text { Adj R-squared } & =0.0163 \\ \text { Root MSE } & =96.315\end{array}$

\begin{tabular}{|c|c|c|c|c|c|c|}
\hline lgdpgro & Coef. & Std. Err. & t & $P>|t|$ & [95\% Conf. & Interval] \\
\hline lpopgro & .1292903 & .0503661 & 2.57 & 0.011 & .0302189 & .2283618 \\
\hline _cons & 280.3133 & 41.14543 & 6.81 & 0.000 & 199.3791 & 361.2475 \\
\hline
\end{tabular}

\begin{tabular}{|c|c|c|}
\hline Variable & ols & ols_dum \\
\hline lpopgro & .12929031 * & .05814148 \\
\hline _Icountry_2 & & 4.8024968 \\
\hline _Icountry_3 & & 23.983916 \\
\hline -Icountry_4 & & $-61.154368 *$ \\
\hline _Icountry_5 & & -55.759953 \\
\hline _Icountry_6 & & $71.522809 * *$ \\
\hline _Icountry_7 & & 22.472556 \\
\hline _Icountry_8 & & 86.099647 \\
\hline _Icountry_9 & & $-87.803317 \star \star$ \\
\hline _Icountry_10 & & 10.780687 \\
\hline _cons & $280.31333 * \star *$ & 341.84296 \\
\hline $\mathrm{N}$ & 339 & 339 \\
\hline
\end{tabular}

legend: * $\mathrm{p}<0.05 ; * \star \mathrm{p}<0.01 ; * \star * \mathrm{p}<0.001$ 


\section{Appendix 3 Panel estimation techniques}

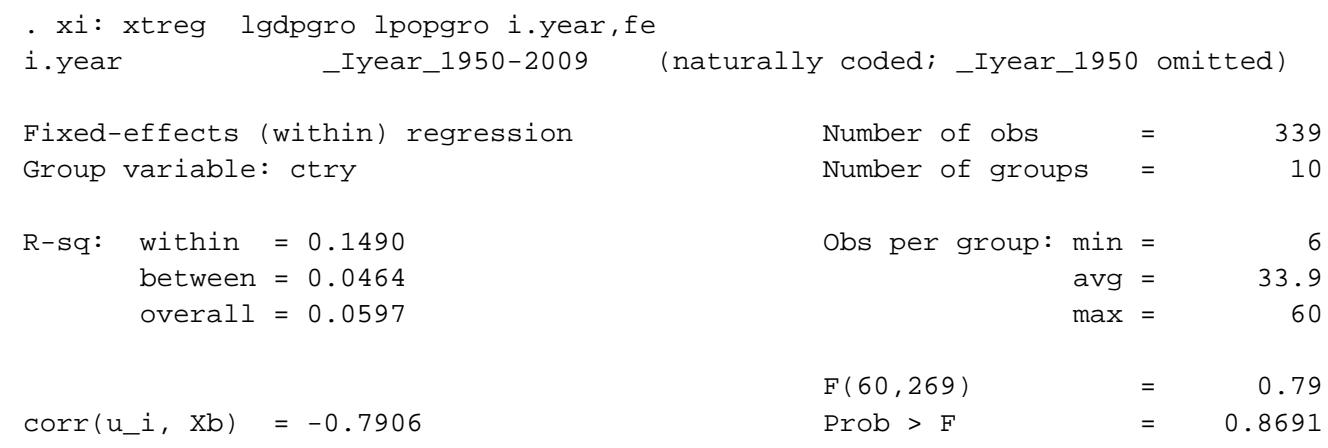

\begin{tabular}{|c|c|c|c|c|c|c|}
\hline lgdpgro & Coef. & Std. Err. & t & $P>|t|$ & [95\% Conf. & Interval] \\
\hline lpopgro & .7605937 & .4349449 & 1.75 & 0.081 & -.0957353 & 1.616923 \\
\hline _Iyear_1951 & -40.98947 & 71.56379 & -0.57 & 0.567 & -181.8858 & 99.90689 \\
\hline _Iyear_1952 & -37.99571 & 71.45078 & -0.53 & 0.595 & -178.6696 & 102.6782 \\
\hline _Iyear_1953 & -29.75784 & 71.34648 & -0.42 & 0.677 & -170.2264 & 110.7107 \\
\hline _Iyear_1954 & -41.06829 & 71.25146 & -0.58 & 0.565 & -181.3497 & 99.21316 \\
\hline _Iyear_1955 & -33.02969 & 71.1641 & -0.46 & 0.643 & -173.1391 & 107.0798 \\
\hline _Iyear_1956 & -34.36171 & 71.08532 & -0.48 & 0.629 & -174.3161 & 105.5926 \\
\hline _Iyear_1957 & -22.94429 & 71.01376 & -0.32 & 0.747 & -162.7577 & 116.8692 \\
\hline _Iyear_1958 & -19.70167 & 70.94973 & -0.28 & 0.781 & -159.3891 & 119.9857 \\
\hline _Iyear_1959 & -20.82628 & 70.89659 & -0.29 & 0.769 & -160.409 & 118.7565 \\
\hline _Iyear_1960 & -109.6238 & 60.4036 & -1.81 & 0.071 & -228.5477 & 9.300167 \\
\hline _Iyear_1961 & -87.74264 & 60.40654 & -1.45 & 0.148 & -206.6724 & 31.18708 \\
\hline _Iyear_1962 & -77.87545 & 60.41447 & -1.29 & 0.198 & -196.8208 & 41.06989 \\
\hline _Iyear_1963 & -68.6982 & 60.42612 & -1.14 & 0.257 & -187.6665 & 50.27006 \\
\hline _Iyear_1964 & -66.45111 & 60.44104 & -1.10 & 0.273 & -185.4488 & 52.54655 \\
\hline _Iyear_1965 & -62.68548 & 60.4597 & -1.04 & 0.301 & -181.7199 & 56.34889 \\
\hline _Iyear_1966 & -60.85861 & 60.48429 & -1.01 & 0.315 & -179.9414 & 58.2242 \\
\hline _Iyear_1967 & -54.70754 & 60.51841 & -0.90 & & -173.8575 & 64.44242 \\
\hline _Iyear_1968 & -198.34 & 60.56466 & -3.27 & & -317.581 & -79.09895 \\
\hline _Iyear_1969 & -156.2577 & 60.61089 & -2.58 & & -275.58 & -36.92568 \\
\hline _Iyear_1970 & -145.06 & & -2.84 & & -245.61 & -44.5227 \\
\hline _Iyear_1971 & -138.35 & 51 & -2.70 & & -239.0 & -37.64727 \\
\hline Iyear_1972 & -129.4338 & 51.24072 & -2.53 & 0.012 & -230.3177 & -28.54999 \\
\hline Iyear_1973 & -122.658 & 51.32261 & -2.39 & 0.018 & -223.7031 & -21.61294 \\
\hline Iyear_1974 & -125.865 & 51.42468 & -2.45 & 0.015 & -227.111 & -24.61893 \\
\hline _Iyear_1975 & -119.0212 & 51.5398 & -2.31 & 0.022 & -220.4939 & -17.54848 \\
\hline _Iyear_1976 & -110.8254 & 51.6613 & -2.15 & 0.033 & -212.5373 & -9.113524 \\
\hline _Iyear_1977 & -104.646 & 51.7932 & -2.02 & 0.044 & -206.6176 & -2.674423 \\
\hline _Iyear_1978 & -96.13875 & 51.91444 & -1.85 & 0.065 & -198.349 & 6.071541 \\
\hline _Iyear_1979 & -93.70237 & 52.03819 & -1.80 & 0.073 & -196.1563 & 8.751567 \\
\hline _Iyear_1980 & -93.30143 & 52.16077 & -1.79 & 0.075 & -195.9967 & 9.393845 \\
\hline _Iyear_1981 & -97.08487 & 52.29739 & -1.86 & 0.064 & -200.0491 & 5.879381 \\
\hline _Iyear_1982 & -97.20503 & 52.42912 & -1.85 & 0.065 & -200.4286 & 6.018566 \\
\hline _Iyear_1983 & -97.628 & 52.55625 & -1.86 & & & 45729 \\
\hline _Iyear_1984 & -95.16 & & -1.8 & & & 7902 \\
\hline _Iyear_1985 & -92.94 & 52.8105 & -1.76 & & & 3207 \\
\hline _Iyear_1986 & -88.78871 & 52.93538 & -1.68 & & & 15.43164 \\
\hline _Iyear_1987 & -90.26075 & 53.06046 & -1.70 & 0.090 & -194.7273 & 14.20585 \\
\hline _Iyear_1988 & -86.13444 & 53.18221 & -1.62 & 0.106 & -190.8407 & 18.57186 \\
\hline Iyear_1989 & -84.9631 & 53.31231 & -1.59 & 0.112 & -189.9255 & 19.99934 \\
\hline _Iyear_1990 & -133.1667 & 45.76825 & -2.91 & 0.004 & -223.2762 & -43.05715 \\
\hline _Iyear_1991 & -109.3995 & 45.79388 & -2.39 & 0.018 & -199.5595 & -19.23946 \\
\hline _Iyear_1992 & -115.1622 & 45.67449 & -2.52 & 0.012 & -205.0871 & -25.23725 \\
\hline _Iyear_1993 & -111.2897 & 45.56029 & -2.44 & 0.015 & -200.9898 & -21.58964 \\
\hline _Iyear_1994 & -101.2953 & 45.55359 & -2.22 & 0.027 & -190.9822 & -11.60843 \\
\hline _Iyear_1995 & -91.89233 & 45.56847 & -2.02 & 0.045 & -181.6085 & -2.176119 \\
\hline
\end{tabular}




\begin{tabular}{r|rrrrrr}
-Iyear_1996 & -80.682 & 45.56079 & -1.77 & 0.078 & -170.3831 & 9.019093 \\
-Iyear_1997 & -79.65478 & 45.58771 & -1.75 & 0.082 & -169.4089 & 10.09931 \\
-Iyear_1998 & -73.52062 & 45.68832 & -1.61 & 0.109 & -163.4728 & 16.43155 \\
-Iyear_1999 & -68.16816 & 45.75291 & -1.49 & 0.137 & -158.2475 & 21.91118 \\
-Iyear_2000 & -63.60586 & 45.79475 & -1.39 & 0.166 & -153.7676 & 26.55584 \\
-Iyear_2001 & -134.7835 & 47.13355 & -2.86 & 0.005 & -227.581 & -41.98589 \\
-Iyear_2002 & -107.8351 & 47.17669 & -2.29 & 0.023 & -200.7176 & -14.9526 \\
Iyear_2003 & -97.18599 & 45.92017 & -2.12 & 0.035 & -187.5946 & -6.777339 \\
-Iyear_2004 & -90.45919 & 45.96222 & -1.97 & 0.050 & -180.9506 & .0322352 \\
-Iyear_2005 & -90.43073 & 45.8519 & -1.97 & 0.050 & -180.705 & -.1565113 \\
-Iyear_2006 & -131.8986 & 44.79873 & -2.94 & 0.004 & -220.0993 & -43.69785 \\
-Iyear_2007 & -149.4817 & 44.81625 & -3.34 & 0.001 & -237.717 & -61.24651 \\
Iyear_2008 & -188.2529 & 44.82956 & -4.20 & 0.000 & -276.5143 & -99.99146 \\
-Iyear_2009 & -106.2316 & 44.839 & -2.37 & 0.019 & -194.5116 & -17.95161 \\
-cons & -132.7358 & 341.1825 & -0.39 & 0.698 & -804.4635 & 538.9918 \\
-------------+----------------------------------------------------------- \\
sigma_u & 87.310538 & & & & &
\end{tabular}

\section{testparm}

- testparm_Iyear*
( 1) _Iyear_1951 = 0
(2) _Iyear_1952 = 0
( 3$)$-Iyear_1953 =0
(4) _Iyear_1954 = 0
( 5) -Iyear_1955 =0
( 6) _Iyear_1956 = 0
( 7) _Iyear_1957 =0
( 8) _Iyear_1958 = 0
(9) _Iyear_1959 =
(10) _Iyear_1960 = 0
(11) Iyear_1961 =0
(12) -Iyear_1962 = 0
(13) _Iyear_1963 = 0
(14) _Iyear_1964 = 0
(15) -Iyear_1965 =0
(16) _Iyear_1966 = 0
(17) _Iyear_1967 = 0
(18) _Iyear_1968 = 0
(19) _Iyear_1969 = 0
(20) Iyear_1970 =0
(21) _Iyear_1971 = 0
(22) _Iyear_1972 = 0
(23) -Iyear_1973 =0
(24) Iyear_1974 =0
(25) _Iyear_1975 = 0
(26) _Iyear_1976 = 0
(27) _Iyear_1977 = 0
(28) _Iyear_1978 = 0
(29) _Iyear_1979 = 0
(30) -Iyear_1980 = 0
(31) _Iyear_1981 = 0
(32) -Iyear_1982 =0
(33) -Iyear_1983 =0
(34) _Iyear_1984 =0
(35) _Iyear_1985 = 0
(36) Iyear_1986 =0
(37) _Iyear_1987 = 0
(38) -Iyear_1988 = 0
(39) -Iyear_1989=0
(40) _Iyear_1990 = 0
(41) Iyear_1991 = 0 


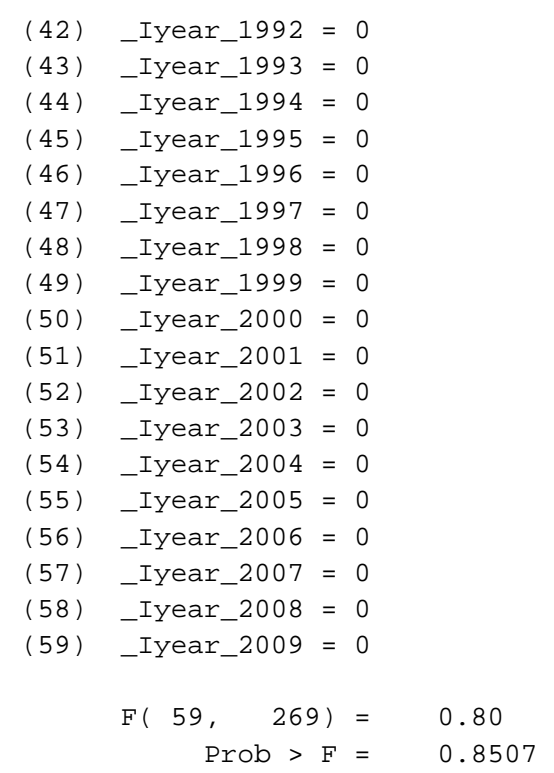

.We failed to reject the null that all years coefficients are jointly equal to zero therefore no time fixedeffects are needed.

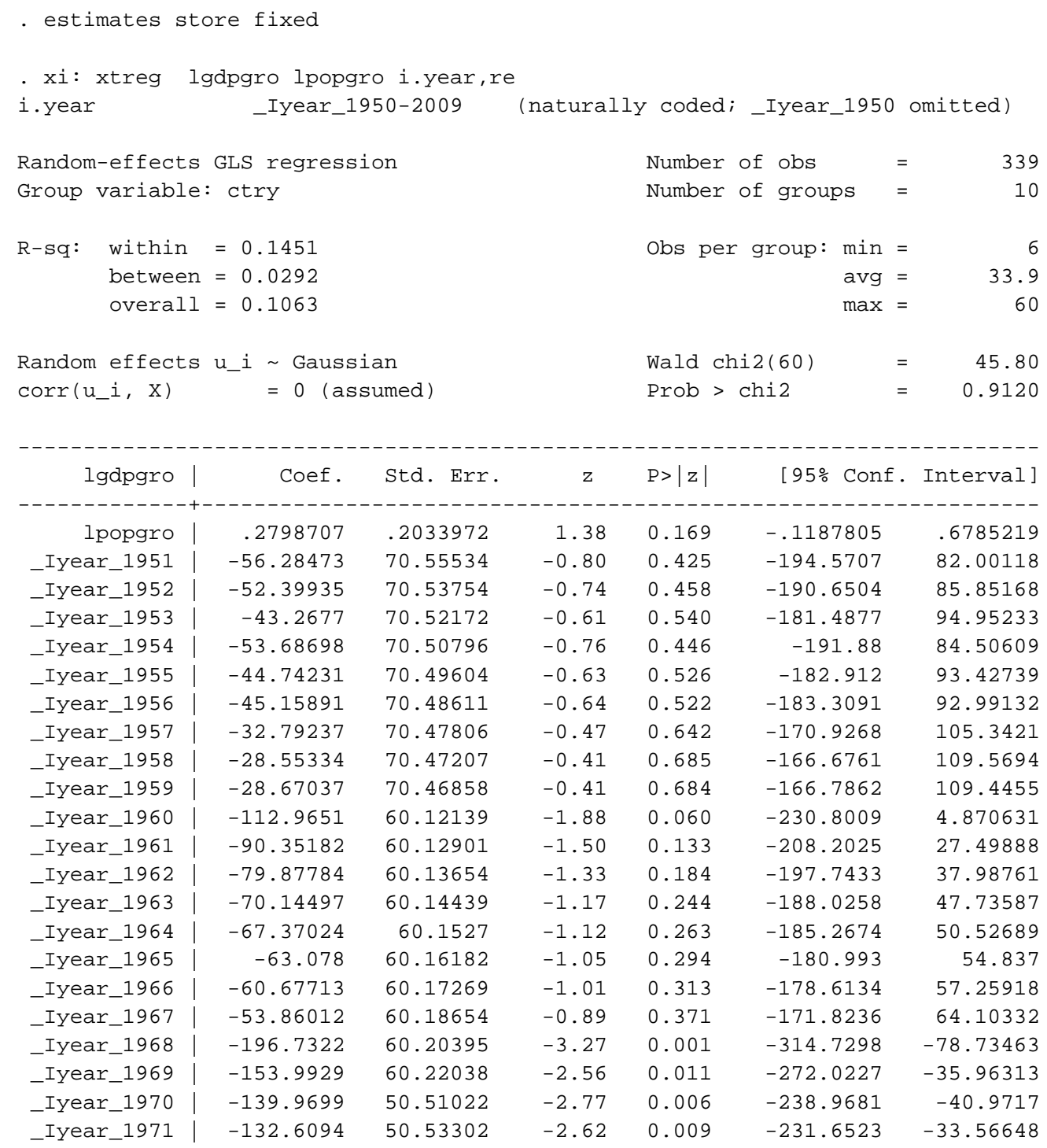




\begin{tabular}{|c|c|c|c|c|c|c|}
\hline _Iyear_1972 & -123.0217 & 50.55826 & -2.43 & 0.015 & -222.114 & -23.92932 \\
\hline _Iyear_1973 & -115.6844 & 50.58061 & -2.29 & 0.022 & -214.8206 & -16.54824 \\
\hline _Iyear_1974 & -118.2342 & 50.60818 & -2.34 & 0.019 & -217.4244 & -19.04395 \\
\hline _Iyear_1975 & -110.6957 & 50.63897 & -2.19 & 0.029 & -209.9463 & -11.44513 \\
\hline _Iyear_1976 & -101.8109 & 50.67118 & -2.01 & 0.045 & -201.1246 & -2.497197 \\
\hline _Iyear_1977 & -94.92584 & 50.70588 & -1.87 & 0.061 & -194.3075 & 4.455856 \\
\hline _Iyear_1978 & -85.80285 & 50.73757 & -1.69 & 0.091 & -185.2467 & 13.64096 \\
\hline _Iyear_1979 & -82.76576 & 50.76976 & -1.63 & 0.103 & -182.2727 & 16.74113 \\
\hline _Iyear_1980 & -81.79398 & 50.8015 & -1.61 & 0.107 & -181.3631 & 17.77514 \\
\hline _Iyear_1981 & -84.96605 & 50.83676 & -1.67 & 0.095 & -184.6043 & 14.67216 \\
\hline _Iyear_1982 & -84.51868 & 50.87063 & -1.66 & 0.097 & -184.2233 & 15.18593 \\
\hline _Iyear_1983 & -84.41229 & 50.90325 & -1.66 & 0.097 & -184.1808 & 15.35623 \\
\hline _Iyear_1984 & -81.43782 & 50.93568 & -1.60 & 0.110 & -181.2699 & 18.39429 \\
\hline _Iyear_1985 & -78.71435 & 50.96827 & -1.54 & 0.122 & -178.6103 & 21.18163 \\
\hline _Iyear_1986 & -74.08371 & 51.00012 & -1.45 & 0.146 & -174.0421 & 25.87469 \\
\hline _Iyear_1987 & -75.0899 & 51.03199 & -1.47 & 0.141 & -175.1108 & 24.93096 \\
\hline _Iyear_1988 & -70.52065 & 51.06297 & -1.38 & 0.167 & -170.6022 & 29.56093 \\
\hline _Iyear_1989 & -68.88661 & 51.09605 & -1.35 & 0.178 & -169.033 & 31.25982 \\
\hline _Iyear_1990 & -116.5801 & 43.00243 & -2.71 & 0.007 & -200.8633 & -32.29684 \\
\hline _Iyear_1991 & -92.7368 & 43.00835 & -2.16 & 0.031 & -177.0316 & -8.441991 \\
\hline _Iyear_1992 & -98.85596 & 42.98083 & -2.30 & 0.021 & -183.0968 & -14.61508 \\
\hline _Iyear_1993 & -95.33006 & 42.95457 & -2.22 & 0.026 & -179.5195 & -11.14065 \\
\hline _Iyear_1994 & -85.35618 & 42.95303 & -1.99 & 0.047 & -169.5426 & -1.169792 \\
\hline _Iyear_1995 & -75.90763 & 42.95645 & -1.77 & 0.077 & -160.1007 & 8.285464 \\
\hline _Iyear_1996 & -64.72078 & 42.95468 & -1.51 & 0.132 & -148.9104 & 19.46886 \\
\hline _Iyear_1997 & -63.61137 & 42.96087 & -1.48 & 0.139 & -147.8131 & 20.59039 \\
\hline _Iyear_1998 & -57.17279 & 42.98402 & -1.33 & 0.183 & -141.4199 & 27.07433 \\
\hline _Iyear_1999 & -51.62716 & 42.9989 & -1.20 & 0.230 & -135.9034 & 32.64913 \\
\hline _Iyear_2000 & -46.94064 & 43.00855 & -1.09 & 0.275 & -131.2358 & 37.35456 \\
\hline _Iyear_2001 & -117.3597 & 44.41108 & -2.64 & 0.008 & -204.4038 & -30.31559 \\
\hline _Iyear_2002 & -90.2815 & 44.42131 & -2.03 & 0.042 & -177.3457 & -3.217338 \\
\hline _Iyear_2003 & -80.1525 & 43.03751 & -1.86 & 0.063 & -164.5045 & 4.199475 \\
\hline _Iyear_2004 & -73.3036 & 43.04724 & -1.70 & 0.089 & -157.6746 & 11.06743 \\
\hline _Iyear_2005 & -70.34215 & 43.00249 & -1.64 & 0.102 & -154.6255 & 13.94118 \\
\hline _Iyear_2006 & -112.5712 & 41.85031 & -2.69 & 0.007 & -194.5963 & -30.54614 \\
\hline _Iyear_2007 & -130.1051 & 41.8544 & -3.11 & 0.002 & -212.1383 & -48.07203 \\
\hline _Iyear_2008 & -168.8389 & 41.85751 & -4.03 & 0.000 & -250.8782 & -86.79974 \\
\hline _Iyear_2009 & -86.79124 & 41.85971 & -2.07 & 0.038 & -168.8348 & -4.747705 \\
\hline _cons & 256.9051 & 155.7634 & 1.65 & 0.099 & -48.38564 & 562.1958 \\
\hline sigma_u & 71.607679 & & & & & \\
\hline sigma_e & 89.598029 & & & & & \\
\hline rho & .38977407 & (fra & E vari & e due & u_i) & \\
\hline
\end{tabular}

- estimates table fixed random, star stats(N r2 r2_a)

\begin{tabular}{|c|c|c|}
\hline Variable & fixed & random \\
\hline lpopgro & .7605937 & .27987068 \\
\hline _Iyear_1951 & -40.989471 & -56.284735 \\
\hline _Iyear_1952 & -37.995715 & -52.39935 \\
\hline _Iyear_1953 & -29.757835 & -43.267699 \\
\hline _Iyear_1954 & -41.068291 & -53.68698 \\
\hline _Iyear_1955 & -33.029687 & -44.742312 \\
\hline _Iyear_1956 & -34.361712 & -45.158912 \\
\hline _Iyear_1957 & -22.944289 & -32.792366 \\
\hline _Iyear_1958 & -19.701667 & -28.553338 \\
\hline _Iyear_1959 & -20.82628 & -28.670366 \\
\hline _Iyear_1960 & -109.62376 & -112.96512 \\
\hline _Iyear_1961 & -87.742636 & -90.351818 \\
\hline _Iyear_1962 & -77.875454 & -79.877844 \\
\hline _Iyear_1963 & -68.698204 & -70.144973 \\
\hline
\end{tabular}




\begin{tabular}{|c|c|c|}
\hline _Iyear_1964 & -66.451109 & -67.370239 \\
\hline _Iyear_1965 & -62.685482 & -63.078 \\
\hline _Iyear_1966 & -60.858608 & -60.677127 \\
\hline _Iyear_1967 & -54.707543 & -53.860119 \\
\hline _Iyear_1968 & $-198 \cdot 33999 * \star$ & $-196.7322 * \star$ \\
\hline _Iyear_1969 & $-156.25773^{*}$ & $-153.9929 *$ \\
\hline _Iyear_1970 & $-145.0668 * \star$ & $-139.96991 * \star$ \\
\hline _Iyear_1971 & $-138 \cdot 35133 * *$ & $-132.60937 * \star$ \\
\hline _Iyear_1972 & $-129.43385 *$ & $-123.02167 \star$ \\
\hline _Iyear_1973 & $-122.65802 *$ & $-115.68442 *$ \\
\hline _Iyear_1974 & $-125.86497 *$ & $-118.23417 *$ \\
\hline _Iyear_1975 & $-119.02118 *$ & $-110.69569 *$ \\
\hline _Iyear_1976 & $-110.82543 *$ & $-101.81088 *$ \\
\hline _Iyear_1977 & -104.64602 * & -94.925836 \\
\hline _Iyear_1978 & -96.138746 & -85.802845 \\
\hline _Iyear_1979 & -93.702372 & -82.765761 \\
\hline _Iyear_1980 & -93.301426 & -81.79398 \\
\hline _Iyear_1981 & -97.084873 & -84.966048 \\
\hline _Iyear_1982 & -97.205033 & -84.518683 \\
\hline _Iyear_1983 & -97.628174 & -84.412295 \\
\hline _Iyear_1984 & -95.165505 & -81.437819 \\
\hline _Iyear_1985 & -92.942442 & -78.714345 \\
\hline _Iyear_1986 & -88.788709 & -74.083709 \\
\hline _Iyear_1987 & -90.260748 & -75.089896 \\
\hline _Iyear_1988 & -86.134437 & -70.520653 \\
\hline _Iyear_1989 & -84.963103 & -68.886611 \\
\hline _Iyear_1990 & $-133.16668 * \star$ & $-116.58006 * *$ \\
\hline _Iyear_1991 & $-109.39946 *$ & $-92.736801 *$ \\
\hline _Iyear_1992 & $-115.16219 *$ & $-98.855958 *$ \\
\hline _Iyear_1993 & -111.28974 * & $-95.33006 *$ \\
\hline _Iyear_1994 & $-101.29533 *$ & $-85.356181 *$ \\
\hline _Iyear_1995 & $-91.892333 *$ & -75.907629 \\
\hline _Iyear_1996 & -80.682 & -64.720779 \\
\hline _Iyear_1997 & -79.654784 & -63.611366 \\
\hline _Iyear_1998 & -73.520622 & -57.172791 \\
\hline _Iyear_1999 & -68.168159 & -51.62716 \\
\hline _Iyear_2000 & -63.605863 & -46.940641 \\
\hline _Iyear_2001 & $-134.78347 * \star$ & $-117.35971 * \star$ \\
\hline _Iyear_2002 & $-107.8351 *$ & $-90.281499 *$ \\
\hline _Iyear_2003 & $-97.185988 *$ & -80.152504 \\
\hline _Iyear_2004 & -90.459194 & -73.303605 \\
\hline _Iyear_2005 & $-90.430732 *$ & -70.342153 \\
\hline _Iyear_2006 & $-131.89859 * \star$ & $-112.57124 * \star$ \\
\hline _Iyear_2007 & $-149.48174 * \star \star$ & $-130.10514 * \star$ \\
\hline _Iyear_2008 & $-188 \cdot 25289 \star \star \star$ & $-168.83895 * \star \star$ \\
\hline _Iyear_2009 & $-106.23162 *$ & $-86.791237 \star$ \\
\hline _cons & -132.73585 & 256.9051 \\
\hline $\mathrm{N}$ & 339 & 339 \\
\hline$r 2$ & .14902846 & \\
\hline r2_a & -.06925048 & \\
\hline
\end{tabular}

\section{Hausman test}

- hausman fixed random

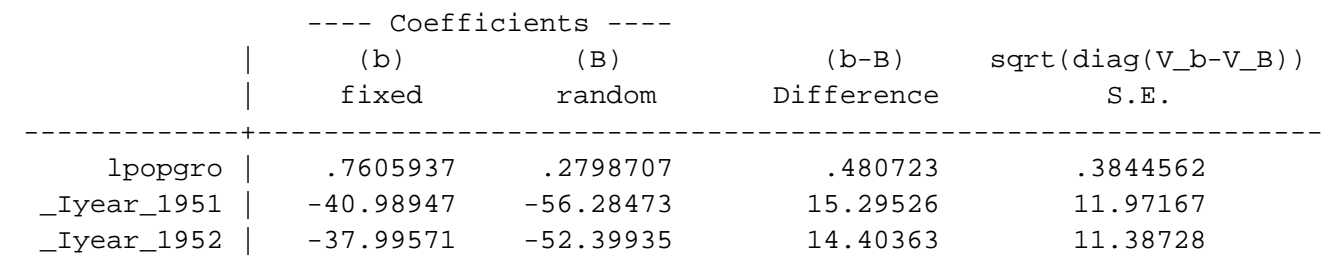




\begin{tabular}{|c|c|c|c|c|}
\hline _Iyear_1953 & -29.75784 & -43.2677 & 13.50986 & 10.81699 \\
\hline _Iyear_1954 & -41.06829 & -53.68698 & 12.61869 & 10.26638 \\
\hline _Iyear_1955 & -33.02969 & -44.74231 & 11.71262 & 9.728177 \\
\hline _Iyear_1956 & -34.36171 & -45.15891 & 10.7972 & 9.210406 \\
\hline _Iyear_1957 & -22.94429 & -32.79237 & 9.848077 & 8.706126 \\
\hline _Iyear_1958 & -19.70167 & -28.55334 & 8.851671 & 8.21897 \\
\hline _Iyear_1959 & -20.82628 & -28.67037 & 7.844086 & 7.778513 \\
\hline _Iyear_1960 & -109.6238 & -112.9651 & 3.341357 & 5.832114 \\
\hline _Iyear_1961 & -87.74264 & -90.35182 & 2.609181 & 5.783722 \\
\hline _Iyear_1962 & -77.87545 & -79.87784 & 2.00239 & 5.788372 \\
\hline _Iyear_1963 & -68.6982 & -70.14497 & 1.446769 & 5.828173 \\
\hline _Iyear_1964 & -66.45111 & -67.37024 & .9191297 & 5.896799 \\
\hline _Iyear_1965 & -62.68548 & -63.078 & .3925173 & 5.994197 \\
\hline _Iyear_1966 & -60.85861 & -60.67713 & -.1814807 & 6.131626 \\
\hline _Iyear_1967 & -54.70754 & -53.86012 & -.8474237 & 6.329167 \\
\hline _Iyear_1968 & -198.34 & $-196 \cdot 7322$ & -1.607786 & 6.600189 \\
\hline _Iyear_1969 & -156.2577 & -153.9929 & -2.264839 & 6.869222 \\
\hline _Iyear_1970 & -145.0668 & -139.9699 & -5.096894 & 7.528222 \\
\hline _Iyear_1971 & -138.3513 & -132.6094 & -5.741962 & 7.916782 \\
\hline _Iyear_1972 & -129.4338 & -123.0217 & -6.412175 & 8.335137 \\
\hline _Iyear_1973 & -122.658 & -115.6844 & -6.973604 & 8.69553 \\
\hline _Iyear_1974 & -125.865 & -118.2342 & -7.630801 & 9.127388 \\
\hline _Iyear_1975 & -119.0212 & -110.6957 & -8.325484 & 9.594054 \\
\hline _Iyear_1976 & -110.8254 & -101.8109 & -9.014546 & 10.06587 \\
\hline _Iyear_1977 & -104.646 & -94.92584 & -9.720186 & 10.55699 \\
\hline _Iyear_1978 & -96.13875 & -85.80285 & -10.3359 & 10.99127 \\
\hline _Iyear_1979 & -93.70237 & -82.76576 & -10.93661 & 11.41952 \\
\hline _Iyear_1980 & -93.30143 & -81.79398 & -11.50745 & 11.83018 \\
\hline _Iyear_1981 & -97.08487 & -84.96605 & -12.11882 & 12.27361 \\
\hline _Iyear_1982 & -97.20503 & -84.51868 & -12.68635 & 12.68822 \\
\hline _Iyear_1983 & -97.62817 & -84.41229 & -13.21588 & 13.07743 \\
\hline _Iyear_1984 & -95.16551 & -81.43782 & -13.72769 & 13.45557 \\
\hline _Iyear_1985 & -92.94244 & -78.71435 & -14.2281 & 13.82702 \\
\hline _Iyear_1986 & -88.78871 & -74.08371 & -14.705 & 14.18247 \\
\hline _Iyear_1987 & -90.26075 & -75.0899 & -15.17085 & 14.53095 \\
\hline _Iyear_1988 & -86.13444 & -70.52065 & -15.61378 & 14.86337 \\
\hline _Iyear_1989 & -84.9631 & -68.88661 & -16.07649 & 15.21169 \\
\hline _Iyear_1990 & -133.1667 & -116.5801 & -16.58663 & 15.66919 \\
\hline _Iyear_1991 & -109.3995 & -92.7368 & -16.66266 & 15.72775 \\
\hline _Iyear_1992 & -115.1622 & -98.85596 & -16.30623 & 15.45338 \\
\hline _Iyear_1993 & -111.2897 & -95.33006 & -15.95968 & 15.187 \\
\hline _Iyear_1994 & -101.2953 & -85.35618 & -15.93915 & 15.17124 \\
\hline _Iyear_1995 & -91.89233 & -75.90763 & -15.9847 & 15.20623 \\
\hline _Iyear_1996 & -80.682 & -64.72078 & -15.96122 & 15.18819 \\
\hline Iyear_1997 & -79.65478 & -63.61137 & -16.04342 & 15.25134 \\
\hline _Iyear_1998 & -73.52062 & -57.17279 & -16.34783 & 15.48539 \\
\hline _Iyear_1999 & -68.16816 & -51.62716 & -16.541 & 15.63405 \\
\hline _Iyear_2000 & -63.60586 & -46.94064 & -16.66522 & 15.72972 \\
\hline _Iyear_2001 & -134.7835 & -117.3597 & -17.42376 & 15.78695 \\
\hline Iyear_2002 & -107.8351 & -90.2815 & -17.5536 & 15.88671 \\
\hline Iyear_2003 & -97.18599 & -80.1525 & -17.03348 & 16.01358 \\
\hline _Iyear_2004 & -90.45919 & -73.3036 & -17.15559 & 16.10779 \\
\hline _Iyear_2005 & -90.43073 & -70.34215 & -20.08858 & 15.9117 \\
\hline _Iyear_2006 & -131.8986 & -112.5712 & -19.32735 & 15.98369 \\
\hline _Iyear_2007 & -149.4817 & -130.1051 & -19.3766 & 16.02204 \\
\hline _Iyear_2008 & -188.2529 & -168.8389 & -19.41394 & 16.05112 \\
\hline _Iyear_2009 & -106.2316 & -86.79124 & -19.44038 & 16.07172 \\
\hline
\end{tabular}

$\mathrm{b}=$ consistent under Ho and Ha; obtained from xtreg $\mathrm{B}=$ inconsistent under Ha, efficient under Ho; obtained from xtreg

Test: Ho: difference in coefficients not systematic

$$
\begin{aligned}
\operatorname{chi2}(60) & = & (b-B) \cdot\left[\left(V \_b-V \_B\right) \wedge(-1)\right](b-B) \\
& = & 2.92 \\
\text { Prob }>\text { chi2 } & = & 1.0000
\end{aligned}
$$




\section{Appendix 4 Unit root tests}

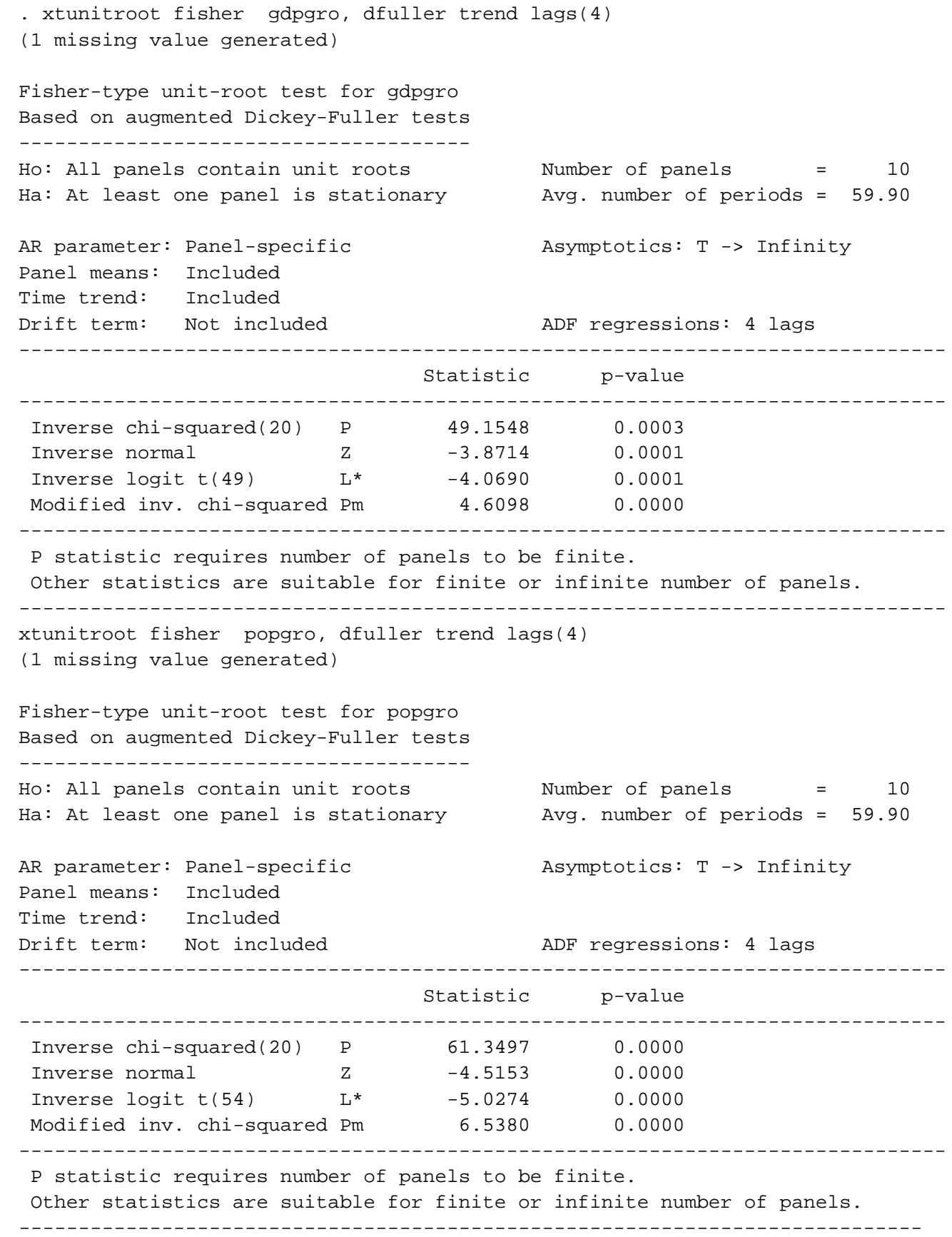


References

[1] Alan Heston, Robert Summers and Bettina Aten, Penn World Table Version 7.0, Center for International Comparisons of Production, Income and Prices at the University of Pennsylvania, May 2011.

[2] Assaf Razin and Uri Ben-Zion,(1973), An intergenerational model of population growth, Discussion Paper No. 73-34,University of Minnesota

[3] Badi H. Baltagi,(2008), Econometric Analysis of Panel Data,Wiley

[4] Birdsall, N., (1988), Handbook of development economics ,Volume 1, edited by T.N.Srinivasan

[5] Greene ,William H.,(2008), Econometric analysis, Upper Saddle River, N.J. : Prentice Hall, 2008

[6] Greene, W.(2001), Estimating Econometric Models with Fixed Effects , Department of Economics, Stern School of Business, New York University

[7] Michael Kremer (1993), "Population Growth and Technological Change: One Million B.C. to 1990," Quarterly Journal of Economics 108:3 (August), pp. 681-716.

[8] Ramsey,F.,P.(1928), A Mathematical theory of saving, The Economic journal Vol.38 No.152

[9] Paul R. Ehrlich and John P. Holdren,(1971), Impact of Population Growth, Science, New Series, Vol. 171, No. 3977 (Mar. 26, 1971), pp. 1212-1217

[10] Podestà,F.(2002), Recent developments in quantitative comparative methodology: The case of pooled time series cross-section analysis, DSS PAPERS SOC 3-02

[11] Wooldridge, J.M., 1995, Selection corrections for panel data models under conditional mean independence assumptions, Journal of Econometrics 68, 115-132. 